Journal of Southeast Asian

\title{
Hmong American Charter Schools: An Exploratory and Descriptive Study
}

Pao Lor

UW-Green Bay, lorp@uwgb.edu

Follow this and additional works at: https://docs.lib.purdue.edu/jsaaea

Part of the Bilingual, Multilingual, and Multicultural Education Commons

\section{Recommended Citation}

Lor, Pao (2021) "Hmong American Charter Schools: An Exploratory and Descriptive Study," Journal of Southeast Asian American Education and Advancement. Vol. 16 : Iss. 1, Article 12.

DOI: $10.7771 / 2153-8999.1195$

Available at: https://docs.lib.purdue.edu/jsaaea/vol16/iss1/12

This document has been made available through Purdue e-Pubs, a service of the Purdue University Libraries. Please contact epubs@purdue.edu for additional information.

This is an Open Access journal. This means that it uses a funding model that does not charge readers or their institutions for access. Readers may freely read, download, copy, distribute, print, search, or link to the full texts of articles. This journal is covered under the CC BY-NC-ND license. 


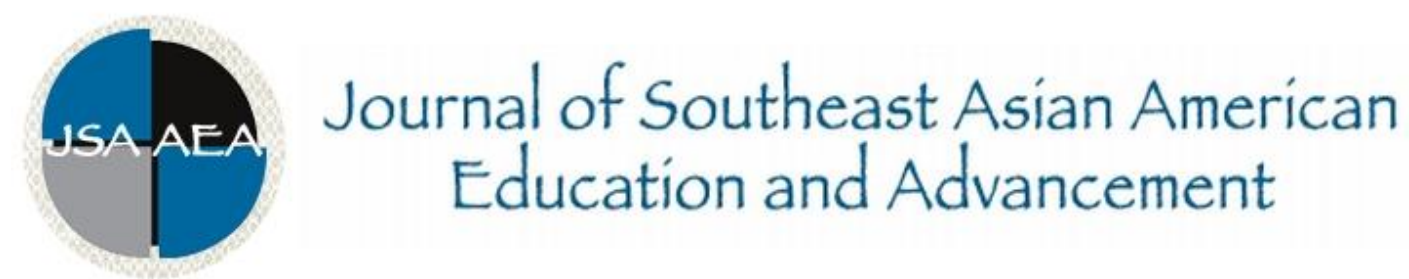

Vol. 16 Iss. 1 (2021)

www.JSAAEA.org

\title{
Hmong American Charter Schools: An Exploratory and Descriptive Study
}

\author{
Pao Lor \\ University of Wisconsin-Green Bay
}

\begin{abstract}
In this exploratory and descriptive study, I explored, analyzed, and described data provided by existing seven Hmong American charter schools. I aggregated my findings into these categories: communities and history; mission, vision, and/or core/value/future/belief statements; governance structure; curriculum; calendar; student support services; co-curricular activities; student information; staff information; student achievement; parental resources and involvement; communications; budgets/school finance; student enrollment; transportation; and other notable(s). For each category, I summarized the data explored and described, and for most of the categories, I provided supporting details to add depth.
\end{abstract}

Keywords: Charter schools, Hmong American charter schools, Hmong American educational experience, Understudied student learning experiences, Understudied school curriculum and reforms, Emerging and innovative school curriculum

\section{Introduction}

America's history of education is experimental, innovative, controversial, and transformative, resulting in many types of schools: public, private, religious, home, international, bicultural, and bilingual. In vein with such history, in 1991, Minnesota passed laws to establish charter schools. In 1992, Minnesota opened the first charter school. According to the Center for Public Education (2016):

Simply put, a charter school is a non-religious, public school operating under a contract, or "charter," that governs its operation. For almost two decades, charter schools have evolved as a way to experiment with education innovations and provide public school choice. All details of school operation — its name, organization, management, and curriculum—are set by the charter, which also outlines how the school will measure student performance.

@

SDDEFIGHISRESERNEDR Readers are free to copy, display, and distribute this article, as long as the work is attributed to the author(s) and the Journal of Southeast Asian American Education \& Advancement, it is distributed for non-commercial purposes only, and no alteration or transformation is made in the work. More details of this Creative Commons license are available at http://creativecommons.org/licenses/by-nc-nd/3.0/. All other uses must be approved by the author(s) or JSAAEA.

Journal of Southeast Asian American Education \& Advancement, Vol. 16. Iss. 1. (2021) ISSN: 2153-8999 
Another definition of public charter school by the National Center for Education Statistics (2019) provides additional clarity:

A public charter school is a publicly funded school that is typically governed by a group or organization under a legislative contract (or charter) with the state or jurisdiction. The charter exempts the school from certain state or local rules and regulations. In return for flexibility and autonomy, the charter school must meet the accountability standards outlined in its charter. A school's charter is reviewed periodically (typically every 3 to 5 years) by the group or jurisdiction that granted it and can be revoked if guidelines on curriculum and management are not followed or if the accountability standards are not met.

In other words, charter schools are established to address learning challenges that public schools may not be able to address within their existing curriculum, policies, pedagogical practices, and governance. For instance, in contrast to existing public schools that aim to be encompassing in educating the public, exchanging breadth for depth, existing charter schools use a curriculum that is driven by a more refined academic discipline or limited to certain pedagogical practices: climate change or environmental science; independent learning or project based; science, technology, engineering and mathematics; bilingual and bi-cultural; business; school to work; technical education; health and dietary; culinary, among others to advance student performance.

Giving these parameters, since 1992, over 6,900 charter schools have been established in forty-two (42) states and in the District of Columbia with an estimate of over 2.5 million students (National Center for Educational Statistics, 2016). Of the 6,900 charter schools, seven are Hmong American charter schools.

In the case of Hmong American charter schools, their establishment and curriculum are seamlessly webbed to the Hmong American diaspora. Hmong Americans have been in the United States since 1975. From the 1960s to the mid-1970s, the United States, specifically the Central Intelligence Agency, recruited and trained many ethnic groups in Southeast Asia including the Hmong to fight in The Secret War in Laos, which is a clandestine military effort to stop North Vietnam's insurgence into Laos. After the United States pulled out of Laos in 1975, the new Laotian regime persecuted the Hmong for supporting the United States during The Secret War. From 1975 to 2014, the United States relocated several waves of Hmong refugees to the United States. Research by Hendricks et al., (1986), Yang (1993), Long (1993), Koltyk (1997), HamiltonMerritt (1999), Hillmer (2010), Lor (2008), and Lor (2009), along with anecdotal stories streaming through the Hmong American communities, capture the details and essence of their diaspora, which includes life in Laos, life in Thailand, and life in the United States - a life that entails the transition and transformation of an ancient and agrarian way of life to a modernized one. According to Hoeffel et al. (2012), in the 2010 US Census, there were 260,073 Hmong Americans residing in the 50 states, District of Columbia, and Puerto Rico.

At the core of the Hmong American diaspora is education. Since the Hmong first arrived on American soil in 1975, teachers, administrators, parents, leaders, and community organizations-given many Hmong American students' minimal experience in a formal educational setting and limited proficiency in English - have made concerted efforts to make the Hmong American students' educational experience a positive and engaging one, driven by the belief education plays a critical role in guiding Hmong American students to become productive and socially responsible citizens and socioeconomically-driven individuals. Hmong National 
Development (HND) in 2003 and 2013 generated two reports that capture the current landscape of the Hmong American formal educational experience. Using educational data from the 2000 and 2010 US Census, HND points out in 2000, 45.3\% of the Hmong American population have no formal education as compared to $1.4 \%$ of the total U.S. population, $27 \%$ of the Hmong American population have a high school diploma, $11.7 \%$ have associate's or bachelor's degrees, and 1.5\% have graduate degrees. In 2010, 14.5\% of the Hmong American population above the age of 25 have attained a bachelor's degree or higher lagging behind $31.4 \%$ of non-Hispanic whites, $18 \%$ of non-Hispanic blacks, and $50.2 \%$ of non-Hispanic Asians.

Adding another perspective to the current landscape of the Hmong American formal educational experience, Pfeiffer et al. (2013) reported that Hmong college graduates are making promising progress, pointing out that their education has helped to pave the way for many to professionally move into politics, education, business, and leadership positions. Adding to that, Xiong (2012) reports the number of Hmong American who are between the ages of 18 and 21 and are attending college in the five most populated states to be increasing: California (76.3\%); Minnesota (54.9\%); Wisconsin (73.1\%); North Carolina (73.8); and Michigan (49.5\%); and as for the rest of the states, it's $83.6 \%$.

Starting in the 2000s, to further advance the achievement of Hmong American students, Minnesota, California, and Wisconsin began establishing Hmong American charter schools. Unlike traditional school or other charter schools' curriculum, per definitions of what a charter school is, Hmong American charter schools' curriculum is driven by dynamics of the Hmong American diaspora, including Hmong language, culture, identity, history, learning experiences, family nuances, and socioeconomic statuses. The establishment of Hmong American charter schools is a fundamental shift from how the majority of Hmong American students were and are presently educated: infusing Hmong American interpreters and paraprofessionals into the classrooms and putting Hmong American students into English learner classes, lower tiered academic classes, school to work pathways, and mainstream classes. The aim of Hmong American charter schools is to improve the achievement of Hmong American students, including academic, well-being, post-secondary, employment, and citizenship.

Though Hmong American charter schools have been in existence for almost two decades, there is no research that I am aware that has explored, examined, and documented their progress. It is this lack of research, along with the needs to explore and examine their progress, to document and preserve their history, and to analyze and share their impact and influence on Hmong American student achievement that gave impetus to this study.

\section{Methodology}

The purpose of the study, in broad strokes, is to gain a better understanding of Hmong American charter schools. In doing so, given that this will be first known study on Hmong American charter schools, I utilized a descriptive and exploratory approach. The study is descriptive in that I explored, analyzed, and described a collection of data that Hmong American charter schools make available to the public on their websites, and the study is exploratory in that I hope my analysis of the available data serves a foundation to further more studies on Hmong American charter schools. 


\section{Sampling}

The sampling is purposeful. Purposeful sampling is a technique widely used in qualitative research for the identification and selection of information-rich cases for the most effective use of limited resources (Patton, 2002). I used these steps to establish my sampling: (a) I knew some of the existing Hmong American charter schools; (b) I asked other Hmong educators if they knew of others; and (c) once I had the list finalized, I confirmed their existence using the National Charter School Resource Center (2019).

The sampling includes seven $(n=7)$ Hmong American charter schools. They are HOPE Community Academy in St. Paul, Minnesota; Hmong American Peace Academy in Milwaukee, Wisconsin; Hmong College Prep Academy in St. Paul, Minnesota; New Millennium Academy in Minneapolis, Minnesota; Community of Excellence in St. Paul, Minnesota; Noble Academy in Minneapolis, Minnesota; and Yav Pem Suab Academy in Sacramento, California.

Following are the Hmong American charter schools and their websites:

1. HOPE (Hmong Open Partnerships in Education) Community Academy: https://hopecommunityacademy.org/

2. Hmong American Peace Academy: https://www.myhapa.org/

3. Hmong College Prep Academy: https://www.hcpak12.org/

4. New Millennium Academy: https://www.newmillenniumacademy.org/

5. Noble Academy: https://www.nobleacademy.us/

6. Community School of Excellence: https://sites.google.com/a/csemn.org/csemn/

7. Yav Pem Suab Academy: https://www.ypsacharter.org/

\section{Data Explored and Described}

The data I explored, analyzed, and described were available to the public on each Hmong American school's website. Upon initial investigation, I concluded that the abundance of data provided on the school websites were feasible and sufficient for the purpose of the study. Data available included student demographics, administrative organization, calendar, curriculum, vision and mission statements, history of each school, student achievement, co-curricular activities, student enrollment policies, among others.

In exploring, analyzing, and describing the data, I used these research questions:

- Where are Hmong American charter schools located, and how did they get started?

- What are their mission, vision, and/or core/value/future/belief statements? Are they different from many of traditional schools' mission, vision, and/or core/value/future/belief statements and why?

- What is their governance structure?

- What are key components of their operational infrastructure, that is, curriculum, calendar, student support services, co-curricular activities, parental resources and involvement, communications, and communities? 
- What information are available about the students they serve and the staff who work there? More specifically, how many students are Hmong Americans, and how many staff are Hmong Americans?

- What is the status of their students' achievement?

- What is the future outlook of these Hmong American charter schools?

- Are any of the aforementioned items any different than from many traditional schools and why?

After several rounds of exploration guided by the aforementioned list of research questions, I codified the data into these categories: locations; communities and history; mission, vision, and/or core/value/future/belief statements; governance structure; curriculum; calendar; student support services; co-curricular activities; student information; staff information; parental resources and involvement; communications; budgets/school finance; student enrollment; transportations; student achievement; and other notable(s). With the codification, I further examined, analyzed the data, and aggregated them into the appropriate category until I achieved saturation, which is when data and analysis become repetitive with no new substantive information or findings. For each category, I shared my analysis based on the data gathered and supported the analysis with evidence.

For the student information category, since many Hmong American charter schools did not aggregate students' racial/ethnic backgrounds or did not provide them, I was not able to provide how many Hmong American students were actually enrolled at each school. However, from examining other relevant information provided by each school, I surmised that the majority of students enrolled at each Hmong American charter school are Hmong Americans.

For the staff information category, since the seven Hmong American charter schools did not list the racial/ethnic backgrounds of their staff, I developed a process to approximate the number of staff who are Hmong Americans. With the exception of HAPA, the other six schools provide a directory of their staff and at times pictures of them. Using these directories, I went through the list and looked at their last names. If a staff has one of these Hmong American Hmong clan names - Cheng (Cha), Cheng, Chue (Chu), Fang, Hang, Her (Herr or Heu), Khang, Kong, Kue, Lee (Le or Ly), Lor (Lo, Lauj, or Lau), Moua, Pha, Thao (Thor or Thoj), Vang (Va), Vue $(\mathrm{Vu})$, Xiong, or Yang (Ya) - I counted the individual as a Hmong American. By no means is this process $100 \%$ correct because at times, clan names like Lee, Hang, and Yang could be of other Asian ethnicity or race, or at times, Hmong Americans could have changed their clan names due to marriage or other circumstances.

It is important to note that though these Hmong American charter schools also serve other racial/ethnic students, parents, and staff, for the purpose of the study, I will only focus relevant topics related to Hmong Americans.

\section{Limitations}

The study has several limitations. One is the study only focused on Hmong American charter schools, not contrasting or comparing them to other charter schools or non-charter schools that could have a high Hmong American student population as well. Other limitations include the data I analyzed are limited to the data each school has made available on its website; since my analysis is exploratory and descriptive, I do not provide statistical analysis of the significance of data the 
schools provided; the data I used in my study are selective and not inclusive; in other words, I might have missed or not included certain information that others might deem important, relevant, and significant; and other researchers' analysis of the data may have different interpretations and conclusions.

\section{Key Research Terms and Definitions}

The following terms and their definitions in Table 1 provide context and clarity to how I interpreted some of the data:

Table 1. Key research terms and definitions.

\begin{tabular}{|c|c|}
\hline Key Research Terms & Definitions \\
\hline Student Support Services & $\begin{array}{l}\text { Student Support Services include special education, } \\
\text { counseling, school psychologist, police school liaison, } \\
\text { paraprofessionals, school-to-work employment, post- } \\
\text { secondary services, administrative, and other } \\
\text { professional services. }\end{array}$ \\
\hline Co-curricular Activities & $\begin{array}{l}\text { Co-curricular activities include athletics, student } \\
\text { academic and non-academic clubs and organizations, } \\
\text { drama, and leadership and community service } \\
\text { activities that typically available to students outside of } \\
\text { the normal academic school day. }\end{array}$ \\
\hline Governance Structure & $\begin{array}{l}\text { Organizational structure of governance for each } \\
\text { Hmong American school, that is, authorizer, school } \\
\text { board, superintendent, principal, associate principal, } \\
\text { department chair, teachers, etc. }\end{array}$ \\
\hline Curriculum & $\begin{array}{l}\text { "A systematic teaching [and learning] method that } \\
\text { engages students in learning knowledge and skills } \\
\text { through an extended inquiry process structured around } \\
\text { complex, authentic questions and carefully designed } \\
\text { products and tasks" (Innovations Academy, 2019). }\end{array}$ \\
\hline Calendar & $\begin{array}{l}\text { The contracted months, days, and activities during } \\
\text { which school is in session as approved by a governing } \\
\text { body-usually by a school board. }\end{array}$ \\
\hline Student Achievement & $\begin{array}{l}\text { Assessments of student achievement in various areas } \\
\text { (math, science, reading, physical abilities, college } \\
\text { readiness, etc.) as measured by each school. }\end{array}$ \\
\hline $\begin{array}{l}\text { Parental Resources and } \\
\text { Involvement }\end{array}$ & $\begin{array}{l}\text { Resources available to support parents and } \\
\text { opportunities for parents to be involved in their } \\
\text { students' achievement, that is, committees, } \\
\text { governance, volunteering, and so forth. }\end{array}$ \\
\hline Communications & $\begin{array}{l}\text { Ways each Hmong American charter schools } \\
\text { communicate relevant information to stakeholders: the } \\
\text { public, authorizer, state and federal education } \\
\text { agencies, parents, and students. }\end{array}$ \\
\hline
\end{tabular}




\begin{tabular}{ll}
\hline Communities & $\begin{array}{l}\text { Relevant information about communities where } \\
\text { Hmong American charter schools are located. }\end{array}$ \\
Budgets/School Finance: & $\begin{array}{l}\text { The amount of money budgeted for each school to } \\
\text { operate. }\end{array}$ \\
Student Enrollment: & $\begin{array}{l}\text { Enrollment information/policy available at each } \\
\text { Hmong American charter school's website. }\end{array}$ \\
\hline
\end{tabular}

\section{Findings}

I codified the findings into these categories: communities and history; mission, vision, and/or core/value/future/belief statements; governance structure; curriculum; calendar; student support services; co-curricular activities; student information; staff information; student achievement; parental resources and involvement; communications; budgets/school finance; student enrollment; transportation; and other notable(s). For each category, I shared my analysis based on the data gathered and supported the analysis with evidence.

\section{Communities and History}

Presently, the seven existing Hmong American charter schools are located in metropolitan areas where there is a concentration of Hmong American population: Minneapolis and St. Paul, Minnesota; Sacramento, California; and Milwaukee, Wisconsin. California has one Hmong American charter school, Wisconsin has one, and Minnesota has five. As it turns out, their location in metropolitan areas where there is a high density of Hmong American population gives them two distinctive advantages: they can efficiently secure sufficient student enrollment and garner community support and investment for a platform/rationale to address common student cultural, emotional, and academic challenges among Hmong American students, parents, and communities. Giving these two critical advantages, it remains to be seen if Hmong American charter schools can exist without them.

Three of the Hmong American charter schools have "Hmong" in their school names: Hmong Open Partnerships in Education Community Academy, Hmong American Peace Academy, and Hmong College Prep Academy. One has a name that is in Hmong-Yav Pem Suab (In the Future) Academy in Sacramento, California. I didn't find any information on how each school names were chosen.

Hmong American charter schools started out with facilities suitable for about 200 to 400 students. Since then, several Hmong American charters have increased their enrollment to the threshold of expanding or needing to expand their facilities and services. Nonetheless, it is important to note that the increase in student enrollment and expansion of services and facilities may not be correlated with increase in student achievement or academic proficiency.

The movement and justifications behind why individuals and organizations started Hmong American charter schools are similar in vein: to advance Hmong American student achievement by using a curriculum that is driven by the Hmong American experience. In other words, these individuals and entities felt that these new and innovative learning opportunities, which is a fundamental shift from how Hmong American students had been and are presently educated, would fundamentally address many Hmong American students' needs and challenges that may have been neglected or otherwise have been adequately addressed via the educational status quo. 
These selected snapshots validate such movement and beginnings:

- "Dr. Christianna Mai-Choua Hang is the Founder and Superintendent of Hmong College Prep Academy (HCPA), the first Hmong-led charter school in the United States. Opening its doors in 2004 to 200 9th and 10th grade students, HCPA was founded on bringing world cultures and college readiness into all aspects of its academic programming. Dr. Hang initiated the development and planning of the Academy in 2000 and has provided the school with strategic management, educational programming expertise and technical support since its inception. In 2017, under her guidance and vision, HCPA's enrollment reached 1,800 K-12th grade students. In 2018, HCPA's enrollment reached 2,200 students, four years earlier than projected, making HCPA one of the largest single-site charter schools in Minnesota" (HCPA, 2019).

- Community School of Excellence (CSE) "began as a gathering of dedicated parents and community members whose work and requests gave birth to the mission and vision of our community school. Among the founding volunteers are parents, community members and educators who continue to be passionate about providing a quality education and a nurturing environment to all students. CSE's journey has led to new and essential initiatives and globally minded areas of focus. Since the inception of our school, we have moved to a larger and more robust school facility, tripled our student enrollment, expanded our curriculum and programs to include a Hmong Cultural Center, and we are taking bold steps toward becoming a center for 21 st Century Learning" (Community School of Excellence, 2018).

- "In 2004, Hmong American Peace Academy, Ltd. opened as the first Hmong Charter School in Wisconsin to respond to the struggle of Milwaukee Hmong families in maintaining the bond with their children necessary to teach basic values, exert discipline and express their love for them. Education became the source of hope for maintaining the Hmong culture and embracing the best American values as well as providing opportunities for success as productive citizens. The Milwaukee Hmong community worked together to bring the school to life and is committed to growing the school to serve every Hmong child in the community. Student enrollment has grown from 200 to over 950. Currently, HAPA, Ltd. has successfully operated two charter schools. The first is a K4-8 charter school and the second is the International Peace Academy High School, which opened in the fall of 2008" (HAPA, 2019).

\section{Mission, Vision, and/or Core/Value/Future/Belief Statements}

Like other school districts and schools, Hmong American charter schools use their mission, vision, and/or their values, beliefs, or philosophy to guide and establish their curriculum, policies, governance, laws, and pedagogical practices. With the exception of Yav Pem Suab Academy, the other six Hmong American charter schools have an aspect of the Hmong American diaspora included in their mission, vision, and/or in their values, beliefs, or philosophy. This is of course consistent with reasons why individuals and entities wanted to establish Hmong American charter schools, which was again to use dynamics of the Hmong American diaspora as pointed out by Levine (1982); Hendricks, et al. (1986); Yang(1992); Hutchison (1997); Hamilton-Merritt (1999); Vang (2001, 2003, 2004, and 2005); Vang (2010); Lor (2008, 2009); Hillmer (2010); Quincy 
(2011); and Pfeifer et al. (2013), to drive, create, and establish their curriculum, polices, governance, laws, and pedagogical practices. It is indeed driven by and the establishment of such "canon" that makes Hmong American charter schools unique, different, and significant in the context of advancing and transforming Hmong student achievement. For examples of statements that capture such essence, please see Tables A1, A2, and A3 in the Appendix.

\section{Governance Structure}

Whereas public schools are governed by a school board, Hmong American charter schools are governed by an authorizer. An authorizer oversees each charter school's operations, with its main purpose to ensure that each charter school is legally in compliance with federal, state, and local school policies and laws. These policies and laws include reporting of student achievement to the appropriate agencies, reporting of each school's goals and the school's efforts to address them, the reporting of costs to operate the school, and the reporting of other student services and community involvement. Aside from this distinctive difference, Hmong American charter schools have similar organizational governance to that of a public school.

More specifically, each Hmong American charter school has a board comprised of these members: board chair, secretary, treasurer, parent, community members, and a teacher. Below the board is the executive director/administrator who oversees the daily operations of the school. Elementary and middle school teachers, specialists, and support staff make up the rest of HOPE's governance structure. More specifically, specialists typically include Reading Specialists/Intervention Specialists/Coaches (title reading), Curriculum Specialists (physical education, teacher-librarian, music, and Hmong cultural/language, technology, and art), English Language Development (English language learner teachers), and Special Education. Support staff is typically broken down into these categories: Student Support (occupational therapy and dean of students), Administrative Support (curriculum development, program compliance, office manager, receptionist, parent liaison/marketing/recruiting, and Karen parent liaison), Cultural Specialists, Custodial Services, and Lunch Staff.

The organizational governance at Yav Pem Suab illustrates the aforementioned structure:

- Authorizer (Urban Charter Schools Collective)

- Board of Directors (3 members)

- Academy Council (12 members with 2 members being non-voting members), and a Discipline Supervisor. Academy Council comprised of Parents and Community Members ( 5 members), Teachers ( 5 members), and Non-voting Facilitator ( 2 members)

- Building Administrator (s)

- Teaching/Student Support Services

\section{Curriculum}

Though each Hmong American charter school curriculum and pedagogical practices are driven by the Hmong American experience, each Hmong American charter school's curriculum and pedagogical practices were uniquely designed to meet the learning needs of its geographicallyserved students and community. For instance, Yav Pem Suav's curriculum and pedagogical practices, serving students in the Sacramento area, are vastly different than Hmong American Peace Academy in Milwaukee, Wisconsin, and other Hmong American charter schools in 
Minnesota. In fact, even Hmong American charter schools in St. Paul, Brooklyn Center, and Brooklyn Park have different curriculum and pedagogical practices. Nonetheless, certain common threads exist among all the Hmong American charter schools: (a) to develop productive, global citizens and life-long learners, (b) to use the Hmong American diaspora to achieve such, and (c) achievement standards are connected to established state or federal standards.

The fabric of Noble Academy's school curriculum and pedagogical practices are poignantly captured with these statements:

- 'Noble Academy's educational approach and curriculum is to fulfill its primary statutory purpose to improve all pupil learning and all student achievement. We do this by the implementation of rigorous standards in core content (reading, mathematics, science, and social studies), providing Hmong language and literacy, having all students on an individualized learning plan (ILP), and implementation of sheltered instruction (including the SIOP Model) for all students in order to best serve the needs of its student population."

- "First, we set high expectations for ourselves, students and our communities by allowing children to be all that they can be. This design element is met by having high expectations for all of our students and by providing content area learning through quality teaching."

- "The second design element at Noble Academy is the use of multiple assessments. We utilize a balanced system of authentic, formative and summative assessments aligned to standards to diagnose the needs of our students. Assessment information is also used to help teachers plan next steps in instruction and provide learners with descriptive feedback they can use to improve the quality of their work."

- "The third design element is the incorporation of Hmong Literacy, Bilingual Education, and Hmong Culture Studies into the curriculum. Our students receive strong daily support in the first language and cultural literacy. Our goal is to develop well-rounded individuals with respect for cultural backgrounds and traditions."

Maychy Vue, HOPE Community Academy's executive director, shares HOPE's curriculum and pedagogical practices:

- "In addition to our K-8 classroom instruction of core curriculum, we have licensed teachers in the areas of Hmong language, Library, Computer Applications, Music, Art, and Physical Education. Our Middle School teachers are licensed to teach their specific content areas. Media and Technology instruction is integrated into each content area."

- "HOPE partners with other organizations to supplement our students learning. The East Side Learning Center provides on-site one-on-one tutoring for our primary students. We also sponsor two Boy Scout troops in which boys aged 11 to 17 may join. In addition, Middle School students participate in the school's newsletter and yearbook clubs, the Student Council, and other community service projects throughout the school year."

- "Finally, HOPE offers an after school academic support program as well as a summer school program. The areas of focus are reading and math." 


\section{Calendar}

The Hmong American charter schools' academic calendars are surprisingly similar to public schools. They included contracted school days and their annual activities are approved by a board. Schools typically runs from late August or early September and go to late May or early June. Schools are off during major holidays, religious observations, and other scheduled staff development days. Major holidays and religious observations include Labor Day, Christmas, New Year, Memorial Day, and Good Friday. Other relevant information and events on their calendars include parent teacher conferences, grading periods, school leadership meetings, community events, sporting meets, academic competitions, and others. Some calendars are more detailed than others. With the exception of Yav Pem Suab Academy, most school days start at around 8:00 am and ends at around 3pm. Yav Pem Suab Academy's school days start at 8:00 am and end at 5:00 pm. Aside, from these standardized starting and ending times, other school related events are scheduled throughout the week, including parent teacher conferences, after school activities, cocurricular activities, leadership and community meetings, and weekend events.

\section{Student Support Services}

Student support services include services that are typically outside of the mainstream classroom. Like most public and private schools, they include counseling, health, administrative services, after school activities, custodial services, special education, food service, among others. Their purpose is to support, advance, and enhance the student experience with the goal of improving student achievement. One key distinctive difference between Hmong American charter schools and most public and private schools in the area of student support services is that many personnel working in the Hmong American charter schools are Hmong Americans who are fluent in Hmong and have a great understanding of the nuances and subtleties of the Hmong American experience, that is, religious practices; cultural practices such as weddings, funerals, and soul callings; clan and tribal dynamics, among others. In turn, they can utilize their cultural dispositions in a potentially positive ways when working Hmong American parents, students, families, and communities.

Here are three samples of student support services provided by Hmong American charter schools highlighting the spectrum of student services available to their students.

- New Millennium Academy’s (NMA) after-school program runs from 4:30 PM to 6:00 or 6:30 PM depending on the program. These programs are provided on site, by NMA teachers and outside organizations. The targeted tutoring sessions are designed to assist children who need additional support for their academic skills. The focus group is those children who are operating just below the expected grade level achievement as shown on their FASTbridge Reading and Math and MCAIII Reading and Math and grade level assessments. Students also have access to support services, including after school programs such as cultural dance, Boy Scouts and Girl Scouts, arts and crafts and sports activities. Any student staying for any afterschool program also has supper provided as the school qualifies for the CACFP Program.

- Community School of Excellence's (CSE) student support services include paraprofessionals, kitchen operations, maintenance, academic coaches, impact coaches, technology and district assessment, EL coordinator, media specialist, safety and security, health aide, transportation, office coordinator, graphic design, human resource 
recruiter, Karen family liaison, health and wellness nurse, evening receptionist, information technology, K-8 Academic administrative assistant, human resource generalist, dance coach, and assistant dance coach.

- Yav Pem Suab Academy's student support services include Front Office Staff, Business Office Staff, Nursing Services Staff, Special Education Service Staff, Site Management Staff, Yard Duty Supervision Staff, Instructional Aide Staff, and Achieving Through Technology Staff.

\section{Co-curricular Activities}

Co-curricular activities include athletics, student academic and non-academic clubs and organizations, drama, and leadership and community service activities that are typically available to students outside of the normal academic school day. The co-curricular activities available at each Hmong American school depends on each school's resources and grade levels. For Hmong American charter schools that have a middle or high school, their student activities expand to include sports, academic clubs and organizations, and other student opportunities.

Aside from social development and growth, participation in co-curricular activities is also instrumental for Hmong American students' academic development and growth. As reported by Sweet (1986); Cheong et al. (1985); and Harvancik and Golsan (1986), participation in student activities has a positive relationship to grades. Without the existence of Hmong American charter schools to provide these activities, many Hmong American students may not be able to participate or be limited in participating in such engaging and critical opportunities in a public school setting.

Here are samples of the arrays of student co-curricular activities available to students:

- Hmong American Peace Academy's (HAPA) co-curricular activities at the K-8 level include student clubs (The Financial Challenge Bowl), drama, knitting, and yearbook and athletics (girls or boys basketball, volleyball, Taekwondo, soccer, and flag football). HAPA also has open gym times. HAPA's co-curricular activities at 9-12 level include clubs (choir, yearbook, open gym, dances, and college readiness activities), athletics (boys and girls basketball, flag football, and volleyball), student council, and college readiness activities and support. All participants must adhere to school activities policies.

- Hmong College Prep Academy (HCPA), in addition to sports (boys soccer, girls soccer, girls volleyball, girls basketball, girls badminton, boys volleyball, etc.), also offers concert band, concert choir, Hmong spelling bee, Hmong/modern dance, theatre, drama, and mock trial.

- In the fall of 2017, New Millennium Academy (NMA) offered a sports program for students in grades 6 through 8. Approximately 166 students participated in this program, with students playing inter-squad games and against students from different grades. NMA also sponsored Boy Scouts and Girl Scouts. In the spring for grade 5-8, NMA offered a sports program and had about 156 students participating. In this program, students played one sport per week including football and volleyball.

- Outside of physical activities (physical education, dance, and Taekwondo) that are infused into Yav Pem Suab Academy's daily class activities, Yav Pem Suab Academy does not seem to offer any other co-curricular activities. 


\section{Student Information}

Like public schools, Hmong American charter schools must report their student demographics which typically include race, gender, income, age, grade level, and other data as required by their authorizers. Reporting of student demographics serve different two key purposes: (a) a school can assess how their pedagogical practices and curriculum are impacting the types of students they are serving, may it be by race, gender, ethnicity, and/or socioeconomic status and make changes in policies and pedagogical practices as needed, and (b) a school can use their demographics to secure state and federal money to support its unique student populations such as bi-cultural and bilingual learners, low socioeconomic students, and/or school-to-work students. For the seven Hmong American charter schools, what they reported and chose to include on their student demographics vary.

For HAPA, they included student racial/ethnic backgrounds, which are available on their School Report Card, which is generated by the Department of Public Instruction (DPI), Wisconsin's state education agency. For HAPA's reported student demographics, please see Table A4 in the Appendix.

HAPA's School Report Card also has their total student enrollment, which is 1,594, with an Asian category comprised of $97.7 \%$ of HAPA's students. Since the Asian category was not aggregated by ethnicity, it is not known how many Hmong American students attend HAPA; nonetheless, drawing from other information they shared (photographs of student population, vision and mission statements, communications, etc.), it can be surmised that majority are Hmong American students. HAPA also included Student Groups, which $92.4 \%$ of their students are economically disadvantaged. From HAPA's $97.7 \%$ of Asian students and their $92.4 \%$ of students being economically disadvantaged, it can be surmised that many of HAPA's Hmong American students come for low socioeconomic status background.

Unlike HAPA, HCPA does not provide racial/ethnic backgrounds of their students; instead, their reported student demographics are based on grade levels and by special population. For the 2017-2018 academic year, they reported 818 elementary students, 498 middle school students, and 502 high school students, with a total student population of 1,818 , which is a $24 \%$ increase of total student population when compared to their 2016-2017 total student population of 1,469. HCPA's enrollment of special student population is broken into four categories: English learners, special education, free/reduced lunch, and homeless, with the highest percentage being free/reduced lunch at $81 \%$. This is followed by English learners at $27 \%$. In other words, when it comes to the student demographic category of socioeconomic status, HCPA is serving the same student population as HAPA's.

NMA is more explicit about their student demographics sharing the student body at NMA is primarily Hmong by home culture and language. NMA students primarily reside in these areas: Minneapolis, Brooklyn Park, Brooklyn Center, and some students are from extended communities. With a couple exceptions, total student enrollment at NMA has been steadily increasing year by year since 2006, having gone from 177 students to almost 664 in 2017. For the number of students enrolled at NMA from 2006 to 2017, please see Table A5 in the Appendix. NMA also provides information on their student attrition: "Each year approximately 75-100 students transition out of NMA. Some of the reasons given by transferring families for SY18, were 8th grade graduation, families moved to a different city/state, or based on previous bus company."

Noble Academy provides the most details about their student demographics. Their demographics include total enrollment, gender, racial and ethnic student background, special 
education, limited English proficiency, and free/reduced lunch. Again, since Asian/Pacific Islanders were not aggregated, it is not known how many Hmong American students attend Noble Academy. Enrollment increase has been steady at Noble Academy, with biggest increase from 2016-2017 to 2017-2018. Noble Academy also shares their student enrollment by grade levels. Starting in 2017-2018, Noble Academy started accepting pre-kindergartners with 60 students enrolled. Noble Academy's estimation of pre-kindergartners for the 2018-2019 is 100 students. Looking at Noble Academy grade level trends, as indicated in the above table, their total student population begins to decline after fifth grade, with the biggest decline in 2017-2018 from 7th grade with 80 students to 8th grade with 46 students. For breakdowns of the aforementioned, see Tables A6 and A7 in the Appendix.

Noble Academy, interestingly enough, also reports on their student attendance for 20152016, 2016-2017, and 2017-2018, with the lowest attendance rate being 95.80\% in 2016-2017 and the highest attendance rate being $99.60 \%$ in $2017-2018$.

For CSE, I was not able to find any racial/ethnic information about their students; however, they provide their 2017-2018 student attrition by grade levels, along with what percentage of their students are special education (10\%), English learners (58\%), and free/reduced lunch at $87 \%$. With the $87 \%$ free/reduced student population, like HAPA and HCPA, CSE also serves similar students, students who are from low socioeconomic status background. CSE's overall student attrition is 9.4\%. For a breakdown of how CSE arrived at a 9.4\% student attrition, see Table A8 in the Appendix.

Of the seven Hmong American charter schools, based on their report student demographics, Yav Pem Suab Academy has the lowest percentage of Asian students at 69.8\%. The next largest racial/ethnic group is Hispanic or Latino at $13.3 \%$. That is followed by Black or African American at $8.9 \%$, White at $4.4 \%$, two or more races at 3.3\%, and Native Hawaiian/Pacific Islander at $0.2 \%$. Like other Hmong American charter schools, Yav Pem Suab Academy's students are of primarily socioeconomically disadvantaged at $87.4 \%$. Their English learners are at $47.3 \%$ and student with disabilities are at $6.8 \%$.

\section{Staff Information}

Aside from wanting to discover the student demographics attending Hmong American charter schools, I also wanted to see the demographics of their staff. Upon my initial exploration, I did not find any reports on the demographics of their staff. With no reports, I went through each school staff directory, counted the number of the total of number of staff, and then counted the number of total staff who have a Hmong American clan surnames. I was not able to find a staff directory on HAPA's website.

From the data, over 400 staff work for the six charter Hmong American schools, and of the 400 or so, $126(30.9 \%)$ of the staff are Hmong Americans. More specifically at CSE, there are one hundred forty-two (142) staff with forty-six (46), approximately 32\%, being Hmong Americans. At Yav Pem Suab Academy, there are twenty-seven (27) staff with 14 (51.8\%) being Hmong Americans. At HOPE, there are sixty-seven (67) staff with twenty-eight (28) being Hmong Americans.

To see the breakdown of staff at HOPE by staff category, number of staff, staff at different grade levels, number of Hmong American staff, and percentage of staff that are Hmong Americans, see Table A9 in the Appendix. For breakdown of HCPA staff, see Table A10, and for breakdown of Noble Academy staff, see Table A11 in the Appendix. 
HCPA also provides the following information about their staff:

- $67 \%$ are teachers

- $5 \%$ are other licensed professionals

- $14 \%$ are paraprofessionals

- $1 \%$ are administrators

- $14 \%$ are other staff including non-licensed staff

- $66 \%$ have a bachelor's degree

- $33 \%$ have master's degree

- $1 \%$ have doctorate

- $46 \%$ have less than 3 years of experience

- $37 \%$ have between 3 and 10 years of experience

- $17 \%$ have more than 10 years of experience

- $100 \%$ of staff are in compliant with licensing requirements (95\% licensed and 5\% with special permission)

From the data, it is important to note that the establishment of Hmong American charter schools provided many Hmong Americans with professional and leadership opportunities they may not otherwise get via the public-school pathways. What is more historically influential is leading each Hmong American charter school is a Hmong American:

- 2000-HOPE (M. Vu)

- 2000-Hmong American Peace Academy (C. Her-Xiong)

- 2004-Hmong College Prep Academy (P. Yang)

- 2005-New Millennium Academy (B. Vang)

- 2006-Noble Academy (N. Thao)

- 2010 - Yav Pem Suab Academy (V. Xiong)

- 2007-Community School of Excellence (V. Vang)

\section{Parental Resources and Involvement}

Based on anecdotal stories and conversations with many Hmong American parents across the US, due to cultural and language challenges, along with unfamiliarity with the American educational system, many do not actively engage with schools, teachers, and administrators in advancing the learning experiences of their children. In this respect, Hmong American charter schools do not only provide many Hmong Americans with professional and leadership opportunities, they also provide Hmong American parents with many opportunities to play an integral part in their children's education, ranging from leadership roles to volunteering for various students support services, again, a trend that is often absent and inadequately addressed in regular public schools.

For Hmong American parents to be more actively engaged in their children's education, they need to be informed and stay informed about school policies, pedagogical practices, curriculum development, among others. Hmong American charter schools have achieved this by providing numerous information that are pertinent for their Hmong American parents in both English and Hmong on their websites as well as via other communications (emails, phone calls, meetings, face to face, and words of mouth) to ensure that school information reaches their Hmong 
American parents and that the parents understand them. A few important reasons for sharing relevant and pertinent school information with their Hmong American parents include transparency, accountability, for them to stay informed and take more ownership of their children's education, and for them to play more an integral role in the decision-making process of creating policies, laws, curriculum, and pedagogical practices that will best meet the needs of their children.

The expansive resources available to parents at HOPE (which are also similar at other Hmong American charter schools but under different titles) are a good example parental resources and involvement: News for Parents, JMC (HOPE's student management data system), Conferences, Food Service Program, Wellness Policy, Online Resources, Request for Services, Suggestion Form, and Make a Donation. Other parental resources and involvement include Hmong School Success Project, Hmong Family Campus Visit, and other capacities as needed including a parent panel on HOPE's 2017-2018 Professional Development and parental survey.

Beyond informing their Hmong American parents with resources or making resources available for them, Hmong American charter schools have historically included Hmong American parents in their decision-making process. Their voices and representations are built into school policies, laws, and governance structure such as serving on leadership boards and committees, volunteering at various school activities, and providing feedback to inform and guide pedagogical practices, policies, and curriculum development. As one example, at NMA, Hmong American parents were surveyed for their opinions on NMA's progress. Based on the survey, Hmong American parents/families continue to be satisfied with NMA's academic program, the flexibility of their staff, and the success the academy has had with their children. Moving forward, Hmong American parents/families want NMA's future planning to address family and staff concerns regarding increasing academic achievement as well as a continued focus on Hmong culture and literacy as a high priority in the education of their children. NMA will use such information in moving their school forward.

One of the most important resources that Hmong American charter schools provide for their Hmong American parents is their diversity of staff, which include many Hmong American leaders and professionals. With many of their staff being Hmong Americans, this has made their learning/teaching dynamics more inclusive, welcoming, and equitable for Hmong American parents.

\section{Communications}

Communications at each Hmong American charter schools attempt to reach a wide range of stakeholders: students, teachers, parents, student support services staff, administration, other educators, authorizer, Minnesota Department of Education, and the general public. Specific communications include student grades, annual reports, parent teacher conferences, public record of minutes from board meetings, letters to parents, student data management system, phone calls, emails, among others. Hmong translation of communications (written, verbal, and electronic) is available, which is critical giving many Hmong American parents and Hmong American children who are yet school-aged are not fluent in English, along with that having school communications in Hmong, in particular, verbal communication, is most culturally and inclusively welcoming and informing. Effective communications are essential for transparency, compliances, and problemsolving. 


\section{Budgets/school Finance}

Each Hmong American charter school's budget/finance information is made available to the public. Each budget includes revenues and expenditures. Revenues include federal and state funds and donations. Expenditures include salaries, benefits, facilities management, staff development, other student services, and discretionary. In addition to the raw financial numbers, specific itemized expenditures are also shared in various formats. The reporting and information included each school's budget/finance vary.

Suab Academy's reporting of their budget/finance is a good representative of what each Hmong American charter school typically includes in the reporting of their school budget/finance. Their budget report has information on how their budget is adopted, the importance of student attendance on the budget, how money in the budget is used, and how the budget is monitored. One highlight from Yav Pem Suab Academy's 2016-1017 budget report is student academic performance. For the 2017- 2018 academic year, Yav Pem Suab Academy aims to improve student performance, and to do so, it plans to invest more money into teaching. Here's their list of such investment:

- Use of \$699,204 in Education Protection Account Funds (EPA) to employ 21 full-time California State Credentialed Teachers

- Provide training to all classroom teachers on the implementation of the "Collaborative Inquiry" process using the Madeline Hunter's 8 step lesson plan model

- Use of \$27,864 in Educator Effectiveness Grant to provide professional development to teachers for implementation of new ELA/ELD adoption and Math pilot

- $\$ 8,000$ budgeted for Multiple Intelligences Training and Coaching for every teacher

- $\$ 25,000$ budgeted for ELD Teacher Training.

- 20,000 budgeted for Teacher Learning Opportunities to visit and observe successful neighboring schools currently implementing the following: 8 step lesson, HET and MI

At Noble Academy, their 2018 annual financial audit report was conducted by Schlenner Wenner \& Co. and has the following details:

- The assets and deferred outflows of resources of the Academy exceeded its liabilities and deferred inflows of resources at the close of the most recent fiscal year by $\$ 2,995,097$ (net position). The unrestricted portion of net position is $\$ 128,970$.

- The Academy's total net position decreased $\$ 1,107,769$ as a result of current year operations.

- At the close of the current fiscal year, the Academy's governmental funds reported combined ending fund balances of $\$ 8,720,329$, an increase of $\$ 26,769$ in comparison with the prior year. Approximately 73 percent of this amount, $\$ 6,399,961$, is available for spending at the Academy's discretion.

- At the end of the current fiscal year, unassigned fund balance for the General Fund is $\$ 3,001,930$, or 30 percent of total General Fund expenditures.

- The Academy's total debt increased by $\$ 5,217,685$ (24 percent) in the current fiscal year, excluding the change in the net pension liability. 
At HCPA, they share that for thirteen (13) consecutive years they have received the School Finance Award from the Department of Education. HCPA also breakdowns their 2016-2017 Revenue Analysis by Source in percentages: 12\% Federal Sources, 3\% Local Sources, and 85\% State Sources; Expenditures in percentages: 6\% Food Service Fund and 94\% General Fund; and Expenditures by Program in percentages: 17\% Sites and Buildings, 0\% Fiscal and Other Fixed Cost Programs, 7\% Food Service, 4\% Administration, 9\% District Support Services, 35\% Regular Instruction, 11\% Special Education Instruction, 7\% Instructional Support Services, and 10\% Pupil Support Services. HCPA's 2017-2018 Revenue Analysis by Source were 11\% Federal Sources, $4 \%$ Local Sources, and 85\% State Sources; Expenditures by fund were 5\% Food Service Fund and 95\% General Fund; and Expenditures by Program were 29\% Sites and Buildings, 0\% Fiscal and Other Fixed Cost Programs, 5\% Food Service, 3\% Administration, 8\% District Support Services, 31\% Regular Instruction, 8\% Special Education Instruction, 6\% Instructional Support Services, and $8 \%$ Pupil Support Services.

\section{Student Enrollment}

Sustainability and expansion of services and facilities at each Hmong American charter school depends on their student enrollment. Increasing student enrollment generates more revenues, more revenues propel growth, and growth means expansion of services and facilities. To make their student enrollment process accessible and efficient, each Hmong American school established student enrollment policies to ensure equality and equity in the admission process and made these policies readily available and explicit to the public on their websites and in their marketing and recruiting strategies. The enrollment policies are consistent at all schools which typically include the following information: purpose, policy statement, general enrollment provisions, application and enrollment procedures, lottery, student recruitment activities, kindergarten and first grade admissions, and pre-kindergarten admissions.

HAPA's enrollment information is a good example of the aforementioned. HAPA included enrollment information on their parents/guardians tab as well as right on their main page. A flyer containing what information are needed for enrollment and a contact person were also provided. Here are HAPA's enrollment instructions:

If you are interested in registering your child at HAPA and would like more information, please contact Mrs. Pua Song at 414-382-4944 Ext: 309 or song.pua@myhapa.org. Feel free to download the Enrollment Application and the Enrollment Checklist to register your child. This is only one piece of the application folder. You will have to come in the main office to pick up the rest of the registration packet. You will need to bring the Enrollment Application and any required documents to HAPA. There will be other documents that are part of the enrollment process that will need to be completed at HAPA.

Yav Pem Suab Academy is also explicit about their enrollment process. They are opened to all students living California including students "who are doing well in school and who are currently attending a school in Program Improvement." They also provided the following additional information:

- As a California public charter school, students living in California attend free of charge. Student are registered and admitted on a space available basis. If space is not available, 
parents can request that their children be placed on the waiting list for the current school year.

- On the first Tuesday of March, a random drawing is conducted to determine who will be enrolled the next school year if there are more new students than available seats. Students currently attending school at YPSA are automatically enrolled for the next year.

- Register in the school office Monday through Thursday 8:00 AM to 5:00 PM. Bring the following items:

1. Birth Certificate or Green Card

2. Proof of address such as a SMUD or PG\&E bill

3. Parent Identification such as a driver's license

4. Immunization records

There is also specific information about to how to enroll as a kindergarten.

Aside from the enrollment process, Hmong American charter schools also share the geographical areas which they serve. For example, HCPA serves these geographical areas: communities in St. Paul, Minneapolis, Bloomington, Brooklyn Center, Brooklyn Park, Coon Rapids, Lino Lakes, Maplewood, Mendota Heights, Oakdale and Roseville. For Noble Academy, their students come from the surrounding communities of Minneapolis, Columbia Heights, Spring Lake Park, Anoka, Coon Rapids, Fridley, Blaine, Brooklyn Park, Brooklyn Center, Crystal, New Hope, North of Golden Valley, and Plymouth. Last year, Noble Academy also strategically increased their overall student population by extending acceptance of students from Maple Grove, Anoka, Ramsey, and Champlin.

\section{Transportation}

Giving that Hmong American charter schools serve students from multiple geographical areas, how do students get to school? With the exception of Yav Pem Suab, the other six Hmong American charter schools offer free transportation to all students who are enrolled. The locations of the other six Hmong American charters, along with the density and concentration of Hmong Americans in these communities, give them a distinct advantage in offering free transportation. An issue worth examining is what would happen if free transportation is not offered, how will this affect their student enrollment?

\section{Student Achievement}

Advancing and improving student achievement is the mission for every Hmong American charter schools. To assess their student achievement, Hmong American charter schools assess academic and non-academic student achievement variables. Academic variables include proficiency in reading, math, and science, and non-academic variables include attendance, parent satisfaction, student growth, closing gaps, on-track and post-secondary readiness, among others. Since state, school district, and at times school get to decide what assessments to use to measure their student achievement, Hmong American charter schools in Minnesota use the same standardized assessments for their students while Wisconsin and California have different assessments. 
In Minnesota, Hmong American charter schools use these assessments: Adequate Yearly Progress; Minnesota Comprehensive Assessments—Series III-MCA-III in reading, science, and mathematics; Northwest Evaluation Association's Measures of Academic Progress; and FASTbridge. HOPE also assesses non-academic goals including attendance and parent satisfaction. At Noble Academy, they assess the following variables:

- Indicator 1: Mission Related Outcomes

- Indicator 2: English Language Learners

- Indicator 3: Reading Growth

- Indicator 4: Math Growth

- Indicator 5: Reading Proficiency

- Indicator 6: Math Proficiency

- Indicator 7: Science Proficiency (and Growth)

- Indicator 8: Proficiency or Growth in Other Curricular Areas or Educational Programs

- Indicator 9: Post-Secondary Readiness

- Indicator 10: Attendance

In Wisconsin, Hmong American Peace Academy's student achievement is reflected in their School Report Card. The School Report Card includes HAPA's performance in Student Achievement, School Growth, Closing Gaps, and On-Track and Post-Secondary Readiness, and Priority Area Weights are put on each of these areas: Student Achievement (5\%), School Growth (45\%), Closing Gaps (25\%), and On-Track and Postsecondary Readiness (25\%), for a total of 100\%. In California, Yav Pem Suab Academy's student achievement is available on their Academic Performance Index (API), School Accountability Report Card, and School Quality Review.

So, how are Hmong American students performing on these assessments? Here are key highlights from each school's reporting of their student achievement.

For all students at HOPE, as indicated on their 2018 report, they scored at a $32.5 \%$ as compared to the statewide average of $61.1 \%$ and comparable schools at $39.4 \%$. For their free/reduced lunch students, HOPE's students scored at $31.6 \%$ as compared to the statewide average of $42.2 \%$ and comparable schools at $28.1 \%$. For their English learner students, HOPE's students scored $10.3 \%$ as compared to the state average of $15.0 \%$ and comparable schools at $12.2 \%$. Though the reading proficiency gap is not significant between HOPE's free/reduced and English learners and the statewide and comparable schools' averages, the gap between HOPE's all students and the statewide average is significant, lagging $28.6 \%$ behind. As for HOPE's students' MCA-III math proficiency in Spring 2018, they follow the same trend as their MCA-III reading proficiency, as indicated by the Table 2 :

Table 2. Percent proficient on the Math MCA-III, Spring 2018: STEP, State of MN, and SPPS (Saint Paul Public Schools)

\begin{tabular}{lrcc}
\hline & HOPE & Statewide & SPPS \\
\hline Mathematics-All students & $35.3 \%$ & $58.7 \%$ & $34.1 \%$ \\
Mathematics-Free / Reduced & $35.3 \%$ & $38.2 \%$ & $23.3 \%$ \\
Mathematics-English Learners $18.4 \%$ & $20.6 \%$ & $16.2 \%$ \\
\hline
\end{tabular}


When the comparison is limited to Free/Reduced-qualifying students, HOPE scores just within 5 points of the statewide group, and ahead of the district; when the comparison is limited to EL students, HOPE is very close to both comparison groups.

In the case of HOPE's math proficiency, though there is not a significant gap (positive or negative) between HOPE's free/reduced and English learners and the statewide and comparable schools' averages, the gap between HOPE's all students and the statewide average is significant, lagging $23.4 \%$ behind.

Here is Table 3 showing HOPE's student achievement in reading proficiency on the MCA-II/III:

Table 3. Percent proficient on the Reading MCA-III, Spring 2018: STEP, State of MN, and SPPS

\begin{tabular}{lccc}
\hline & HOPE & Statewide & SPPS \\
\hline Reading-All students & $32.5 \%$ & $61.1 \%$ & $39.4 \%$ \\
Reading-Free / Reduced & $31.6 \%$ & $42.2 \%$ & $28.1 \%$ \\
Reading-English Learners $10.3 \%$ & $15.0 \%$ & $12.2 \%$ \\
\hline
\end{tabular}

Comparable schools were not identified (not required, per authorizer communication). However, when the comparison is limited to Free/Reduced- qualifying students, HOPE scores just more than 10 points below the statewide group, and slightly ahead of the district; when the comparison is limited to EL students, HOPE is just slightly behind the two comparison groups.

At HCPA, in 2017-2018 report, their students' science proficiency increased 5\% since 2014; their reading proficiency increased 51\% since 2014; and their math proficiency increased $36 \%$ since 2014. In 2016-2017, their science proficiency increased 57\% since 2012; their reading increased 53\% since 2012; and their math proficiency increased $43 \%$ since 2012 . The trajectory of improved proficiency scores demonstrates HCPA's continuous improvement and the effectiveness of their curriculum and student engagement practices. According HCPA, their MCA results serve a number of purposes:

- To ensure HCPA's curriculum are in alignment with Minnesota Academic Standards in mathematics, reading and science utilize results to improve classroom teaching and address opportunities for future improvement.

- Mathematics and reading results are used in federal school accountability standards as well as to check for student mastery of state standard.

Other HCPA's student achievement includes:

- $\quad 98 \%$ of all HCPA seniors took the ACT in 2017-2018

- Class 2018 college readiness proficiency levels have increased $43 \%$ since 2016

- Awards and recognitions in sports

- Graduation rates (2017-2018 at 97\%; 2016-2017 at 87\%; 2015-2016 at 85\%; and 20142015 at $83 \%$ )

- $83 \%$ of 2018 class were accepted to a college or university 
NMA provides their students MCA III proficiency scores in reading and math for 2013 to 2018. For the 2018 report, NMA provides a breakdown by grade levels, number of students tested, and percentage of tested students proficient. However, NMA does not provide any comparable scores to statewide or comparable schools averages. For NMA's other 2013-2018 reports, they did not include grade level but included an On-Track Math and Reading categories. For more specific breakdowns of these reports, see Tables A12, A13, and A14 in the Appendix. NMA continues to strive to improve their student proficiency rate in reading and math, as indicated by these goals:

\section{$\underline{\text { Reading }}$}

Goal: The percentage of all students enrolled October 1 at New Millennium Academy who earn an achievement level of Meets the Standards or Exceeds the Standards on the Reading MCA III (all accountability tests) will increase from $23.8 \%$ in grades 3-8 in 2017-2018 to $29 \%$ in grades 3-8 in 2018-2019. MCA's proficiency goal was $23.8 \%$ in 2018 for students enrolled as of October 1.

\section{$\underline{\text { Math }}$}

Goal: The percentage of all students enrolled October 1 at New Millennium Academy who earn an achievement level of meets the Standards or Exceeds the Standards on the Math MCA III (all accountability tests) will increase from 21.3\% in grades 3-8 in 2017-2018 to $37 \%$ in grades 3-8 in 2018-2019. MCA's Proficiency goal was $21.8 \%$ in 2016 for students enrolled as of October 1. Noble Academy shares their student achievement in areas of Proficiency Index: Reading; Proficiency Rates: and Reading; Proficiency Rates: Math. Their reports are from 2013-2017.

Noble Academy compares their student proficiency scores to statewide averages, district averages, and three comparable schools (Osseo, Prairie Seeds Academy, and Hmong International Academy). Noble Academy's Proficiency Index in Reading ranges from 53.8\% (FY2013) to 75.7\% (FY2017). Noble Academy's Proficiency Rates in Reading remains stable, ranging from 46.7\% (FY2014) to 54.5\% (FY2015). Noble Academy's Proficiency Rates in math, for most part, remains stable, ranging from 59.8\% (FY2017) to 70.5\% (FY2014). For breakdowns of Noble Academy's scores as compared to state scores and other similar schools, see Tables A15, A16, and A17 in the Appendix.

Due to majority of their students being English learners, CSE also uses ACCESS to determine their acquisition of English language skills. According to CSE, their students' ACCESS proficiency improved from $11.7 \%$ to $12.4 \%$ from 2017-2018. Table A18 in the Appendix shows breakdowns of CSE's ACCESS student performance. From their 2017-2018, CSE also shares the following results of their student achievement:

- With respect to the NWEA MAP science, the result is that $58 \%$ of the students made their annual growth. Approximately 192 Grades 6-8 students made their annual science targeted goals. This was another year of record growth for our middle school students.

- The results of the MCA III are as follows: $52 \%$ of grades 4-8 students make their annual expected growth in reading, while $49 \%$ made their annual growth in math. In fact, $29 \%$ these students achieved high growth in reading and 30\% made high growth in math. 
There was an increase of about 5\% in reading high growth from 2017 to 2018.

- According to the Fastbridge results, 65\% of grades K-3 students achieved their expected annual growth in math, while $33 \%$ of these students attained high growth. In Fastbridge K-3 reading, 51\% made their reading annual expected growth and $28 \%$ of these students made high growth. The high growth percentages for K-3 math and reading increased 20\% from 2017 to 2018.

In Wisconsin, based on the Priority Area Weights that HAPA puts on each of these areas: Student Achievement (5\%), School Growth (45\%), Closing Gaps (25\%), and On-Track and Postsecondary Readiness (25\%), for a total of 100\%, HAPA's overall score is $81.2 \%$. According to the Department of Public Instruction's Overall Accountability Ratings, HAPA's 81.2\% falls under the category of "Exceeds Expectations," which is below the highest level "Significantly Exceeds Expectations." This is a significant achievement for HAPA, as many schools in Wisconsin do not meet expectations and need to have a plan for improvements. For additional specific details and analysis of HAPA's student achievement, see data that is available on their School Report Card which is available on their website.

Yav Pem Suab Academy did not provide much data on their student performance in English and math, except for the following:

- The federal AYP or Annual Yearly Progress scores shows 34\% of our 2nd through 6th graders proficient in English Language Arts and 59\% proficient in math (The 2018 AYP scores serve as our baseline).

At the present, Yav Pem Suab Academy is working hard to increase the percentage of proficient students in both English Language Arts and math to $90 \%$, which would be a $31 \%$ increase from their 2018 AYP Report. Achieving this benchmark would put Yav Pem Suab Academy as one of the top ten schools in the Sacramento City Unified School District, and according Yav Pem Suab Academy, the process to achieve this milestone will need to be collaborative that involves staff and parents.

\section{Other Notables}

Aside from the aforementioned categories and analyses, Hmong American charter schools also have other outlying notables that, though they may not be as prevalent as other factors in shaping the transformation of these Hmong American charter schools, are worth highlighting.

School uniform is one of such. With the exception of Yav Pem Suab, the other six Hmong American charter schools required students to be school uniforms. The overarching question with having a school uniform policy is what impact, if any, does it have on the learning and teaching dynamics of Hmong American charter schools? It is important to note that having a school uniform policy is different from having a school dress code policy, which does not require students to wear specific clothes. Here is an example of school uniform policies (HOPE, 2019):

\section{Grades K-5 Uniforms}

- Navy blue bottom (pants, skirt, jumper, shorts). No jeans.

- Belt (blue, black, or brown) at waist level. 
- Collared shirt (white, light blue, navy).

- Socks and shoes must be worn at all times.

- Sweatshirt (cold weather only, navy or white, no pockets or hoods).

\section{Middle School Uniforms}

- Navy blue bottom (pants or skirt). Jeans may be worn on Friday but only if the student has been in compliance with the uniform policy Monday through Thursday.

- Belt (blue, black, or brown) at waist level.

- Collared button-down shirt (white only). No colors or printed t-shirts.

- Socks and shoes must be worn at all times.

- Sweatshirt (cold weather only, navy or white, no pockets or hoods).

Here is HOPE's rationale for uniform adoption:

HOPE Community Academy believes that no child should be treated differently based upon her/his dress or appearance. The goal of the uniform policy at HOPE is to identify our student body in the community through respectful representation. Our expectation is for the student to be neat, clean, and decent.

Another is the amount of information each school shares on its website. Yav Pem Suab Academy includes multiple documents on its website providing historical, legal, and other information about its existence and purpose. These documents include Charter Petition, Memorandum of Understanding (MOU), MOU for Special Education, Facility Use Agreement (FUA), Education Protection Act (EPA) Funding, Local Educational Agency (LEA) Plan, Local Control Accountability Plan (LCAP), Annual Programmatic Audit required by SCUSD, UCSC Board Bylaws, Education Protection Act (EPA), and School Accountability Report Cards (2013, 2014). The sharing of relevant information to the public is important as Hmong American schools continue to operate with transparency and an openness to public discourse about their efforts, progress, and change.

Another is each school's vision for expansion. At HAPA, it "plan[s] to add an early childhood center, adult education center and Hmong culture and research center, as well as a social service center to meet the needs of the refugee population." HAPA has also been featured by news media about their success. There is information about how to support HAPA via donation, sponsorship, volunteering, and tutoring; picture gallery; employment; and how to contact HAPA. These expansions are indications that Hmong American charter schools have established their foundations and purpose and are here for the long run. At the same time, it is also important to note that expansion does not correlate with improvement in Hmong American student academic proficiency, as indicated by standardized state assessments.

\section{Conclusion}

The establishment of Hmong American charter schools have brought many positives as well as challenges in advancing and improving Hmong American student achievement. 
One positive is Hmong American charter schools have provided opportunities for Hmong American students, parents, and professionals that they might not get via the public educational systems: cultural and relevant learning experiences, employment, more parental involvement, and less language barriers. This is evident by the number of Hmong American students enrolled at each Hmong American charter schools, by the number of staff employed who are Hmong Americans, and by the number of Hmong parents who are involved in the day-to-day operations at each school.

Another is some Hmong American charter schools are being recognized for their progress. Noble Academy was identified as a "High Quality Charter School." HOPE has been recognized for 14 straight years by the Department of Education for fiscal accountability. In 2014, the Department of Public Instruction recognized Hmong American Peace Academy in Milwaukee, Wisconsin, as a high-performing school, and then in 2016, DPI again recognized HAPA as a Wisconsin Title 1 School of Recognition (Milwaukee Charter School Advocates, 2016). To qualify for the Wisconsin Title 1 School of Recognition, HAPA met two criteria:

- They are in the top 25 percent of high-poverty schools in the state; and

- They have above-average student achievement in reading and mathematics when compared to similar schools based on size, district, grade configurations, and poverty levels.

Other positive achievements include a steady increase in student enrollment and student proficiency in state and national assessments, efficiency in operating these Hmong American schools, expansion of school facilities and services, and continual support from many entities; nonetheless, again, based on academic data, it is important to note that these variables do not mean Hmong charters are improving Hmong American student's achievement or proficiency.

Lastly, in the long term, if existing Hmong American charter schools are successful in addressing student achievement among Hmong American students, they could serve as educational models for establishing additional Hmong American charter schools in other cities and states where there is also a large concentration and density of Hmong American population such as North Carolina, Oklahoma, South Carolina, and Georgia.

In contrast to these positives, many challenges await. One is diversity. Due to high number of Hmong American students attending Hmong American charter schools, might their learning be at the expense of diversity? In other words, how will their lack of interactions with students from other racial/ethnic backgrounds impact their social and cultural proficiency and competence in the long term? Another is expansion in the number of Hmong American charter schools. Has it saturated? For example, Yav Pem Suab Academy was established in 2010 and there has not been another Hmong American charter school established since. What does this say, if any, about the state of Hmong American charter school moving forward?

Third, in addition to low student academic achievement, leadership and accountability will continue to dictate the future of Hmong American charter schools. In other words, effective leadership and accountability are needed in order for Hmong American charter schools to move forward and vice versa. For instance, Hmong American charter school leadership thus far has ranged from nurturing and collaboratively leadership as demonstrated by HAPA in Milwaukee and other Hmong American charter schools to outright destructive and politically driven at Community of Excellence School (CES) in St. Paul. Du (2016, 2015), and Magan (2016) chronicle the leadership chaos and transition at Community of Excellence, which negatively impacted the culture and dynamics at CES leading to external interventions in order for CES to continue. 
Fourth, giving that existing Hmong American charter schools are located in metropolitan areas, it remains to be seen if Hmong American charter schools can be established in states, regions, or conglomerate of cities where there is a large Hmong American population but the population is not as concentrated. Simply put, could a charter school driven by a curriculum based on the Hmong American diaspora succeed in geographical areas where the majority of students enrolled are not Hmong Americans?

Fifth is academic performance. In 2008, Hmong American students in Hmong American charter schools in Minnesota had an average of $21.75 \%$ of students being considered as proficient versus the state average of $68 \%$ (Moua, 2008), and based on current student achievement data, this trend lingers. Though some Hmong American charter schools are starting to address English language acquisition among their students in effort to address the achievement gap, the future of increasing Hmong student achievement remains a daunting challenge. It is a conundrum to have student enrollment increases at Hmong American charter schools; yet, their student achievement remains low as compared to statewide averages.

Moving forward, amid these positives and challenges, it remains to be seen if the efforts of Hmong American charter schools in the long term do indeed address many of these aforementioned challenges, among other topics that have been studied by other researchers: cultural dynamics influencing their Hmong American diaspora including their perceptions about their family environment by Dung et al. (2012), Hmong American student clubs or associations affecting their cultural and political identities by $\mathrm{Ngo}$ (2015), nutrition and health by Voorhees et. al. (2011); Voorhees et al. (2014), cultural assimilation by Lee (2002), intergenerational family conflict by Su et al. (2005), social well-being by Lee (2007), and particularly language and cultural identity by Bosher (1997).

This exploratory analysis scratches the surface of the statuses of Hmong American charter schools, limiting in perspectives and depth. Moving forward, other study approaches (statistical analysis of Hmong American students test scores, in-depth interviews with various stakeholders, and comparative studies) will add more depth and substance on how Hmong American charter schools have advanced and improved Hmong American students' achievement, social well-being, future economic impact, and so forth. Other potential future studies include:

- Comparing Hmong American student achievement in Hmong American charter schools to other Hmong American students who are in non-Hmong charter schools.

- How have Hmong American charter schools empowered the Hmong American communities, specifically, Hmong American students, Hmong American parents, Hmong American community members, Hmong American community organizations and the Hmong American assimilation into a predominately westernized culture?

- What are the perspectives and experiences of Hmong American and Non-Hmong American teachers, administrators, and other staff about working with predominately Hmong American students and constituents?

- Lastly, there are non-Hmong American charter schools that serve predominately Hmong American students and/or use the Hmong American experience to drive their curriculum and organizational structure. Is their Hmong American student achievement any less or better than that of Hmong American charter school? 


\section{References}

Bosher, S. (1997). Language and cultural identity: a study of Hmong students at the postsecondary level. TESOL Quarterly, 31(3), 593-603. https://doi.org/10.2307/3587843

Center for Public Education (2016, November 6). Corporate Charter schools: Finding out the facts: At a glance. https://www.centerforpubliceducation.org/Main-Menu/Organizing-aschool/Charter-schools-Finding-out-the-facts-At-a-glance.

Cheong, K., Toney, M. B., \& Stinner, W. F. (1986, August). School performance of migrant and native youth in nonmetropolitan areas of Utah. Paper presented at the Rural Sociology Society Annual Meeting [Conference session], Salt Lake City, UT, United States.

Community School of Excellence (2019). https://www.csemn.org/

Du, S. (2016, January 6). The wrath of Mo. City Pages. http://digitalissue.citypages.com/publication/? $\mathrm{m}=5512 \& \mathrm{i}=286956 \& \mathrm{p}=1$

Du, S. (2015, October 22). Head of St. Paul charter school resigns, fires beloved teacher who questioned her. City Pages. http://44.228.233.147/news/head-of-st-paul-charter-school-resignsfires-beloved-teacher-who-questioned-her-7774812

Dung, M., Deenanath, V., \& Xiong, Z. (2012). Hmong students' perceptions of their family environment: a consensual qualitative analysis of family photos. Hmong Studies Journal, 13(1), 1-27. https://hmongstudies.org/MaoDeenanathXiongHSJ13.pdf

Hamilton-Merritt, J. (1999). Tragic mountains: The Hmong, the Americans, and the secret wars for Laos, 1942-1992. Indiana University Press.

Harvancik, M. J., \& Golsan, G. (1986, August). Academic success and extracurricular activities: Is there a relationship? Paper Presented at the American Psychological Association Annual Meeting, Washington, DC, United States.

Hendricks, G. L., B.T. Downing, \& Deinard, A.S. (1986). The Hmong in transition. Center for Migration Studies. https://files.eric.ed.gov/fulltext/ED270509.pdf

Hillmer, P. (2010). A people's history of the Hmong. Minnesota Historical Society Press.

Hmong College Prep Academy (2019). https://www.hcpak12.org

Hmong National Development. (2003). Hmong 2000 census publication: data and analysis. https://hmongstudies.org/HmongCensusReport.pdf

Hmong National Development. (2013). State of the Hmong American community. https://aapidata.com/wp-content/uploads/2017/04/State-of-the-Hmong-AmericanCommunity-2013.pdf

Hoeffel, E.M., S. Rastogi, M.O. Kim, \& Shahid, H. (2012). The Asian American Population: 2010 Census Briefs. U.S. Census Bureau. Washington, DC. United States. https://www.census.gov/prod/cen2010/briefs/c2010br-11.pdf Hmong

American Peace Academy and International Peace Academy. (2019). https://www.myhapa.org.

HOPE (Hmong Open Partnerships in Education) Community Academy (2019). https://www.hopeschool.org/

Hutchison, R. (1997). The educational performance of Hmong students in Wisconsin.

Wisconsin Policy Research, Inc.

Innovations Academy (2019). An inquiry based K-8 public charter school.

https://innovationsacademy.org/our-programs/academic-curriculum/ 
Koltyk, J. A. (1997). New' pioneers in the heartland: Hmong life in Wisconsin. Allyn and Bacon.

Lee, S. J. (2002). Learning "America": Hmong American high school students. Education and Urban Society, 34(2), 233-46. https://doi.org/10.1177/0013124502342007

Lee, S. (2007). The self-rated social well-being of Hmong college students in Northern California. Hmong Studies Journal, 8, 1-19. https://hmongstudies.org/SLeeHSJ8.pdf

Levine, K. (Producer). (1982). Becoming American: The Chinese Experience [Film]. New Day Films.

Long, L. (1993). Ban Vinai, the refugee camp. Columbia University Press.

Lor, P. (2008). Key life experiences contributing to Hmong students' matriculation. Multicultural Education, 16(1), 39-47. https://files.eric.ed.gov/fulltext/EJ822397.pdf

Lor, P. (2009). A photo essay of the Hmong experience at Wat Thamkrabok in Thailand. Hmong Studies Journal, 10, 1-41. https://hmongstudies.org/LorHSJ10.pdf

Magan, C. (2016, July 5). St. Paul charter school averts possible closure. Twin Cities Pioneer Press. $\quad$ https://www.twincities.com/2016/07/05/st-paul-charter-school-averts-possibleclosure/

Milwaukee Charter School Advocates. (2016). More independent charter schools are winning accolades. https://www.milwaukeecharteradvocates.org/blog/category/charter\%20school $\% 20$ success

Moua, W. (2008, March 26). Are Hmong schools making the grades? Twin Cities Daily Planet. https://www.tcdailyplanet.net/are-hmong-schools-making-grades/

National Center for Educational Statistics (2016, December 2). Fast facts: Charter schools. https://nces.ed.gov/fastfacts/display.asp?id=30

National Charter School Resource. (2019). https://charterschoolcenter.ed.gov/charter-schools-usa, New Millennium Academy (2019). www.newmillenniumacademy.org/

Ngo, B. (2015). Hong culture club as a place of belonging: The cultivation of Hmong students' cultural and political identities. Journal of Southeast Asian American Education and Advancement, 10(2), 1-20. https://doi.org/10.7771/2153-8999.1130

Noble Academy, (2019). www.nobleacademy.us/

Patton, M.Q. (2002). Qualitative research and evaluation methods. Sage Publications.

Pfeiffer, M. Chiu, M., \& Yang, K. (2013). Diversity in diaspora: Hmong Americans in the twentyfirst century. University of Hawaii Press.

Quincy, K. (2011). The Hmong: History of a people. GPJ Books.

Su, J., Lee, R.M., \& Vang, S. (2005). Intergenerational family conflict and coping among Hmong American college students. Journal of Counseling Psychology, 52(4), 482-489. https://doi.org/10.1037/0022-0167.52.4.482

Sweet, D. A. (1986, September). Extracurricular activity participants outperform other students. Washington, DC, United States Department of Education, OERI Bulletin. https://files.eric.ed.gov/fulltext/ED279740.pdf

University of Wisconsin-Extension. (2015). Hmong in Wisconsin: A statistical overview. Applied Population Laboratory \& University of Wisconsin-Extension. https://cdn.apl.wisc.edu/ publications/hmong_chartbook_2010.pdf

Vang, C. T. (2001). Histories and academic profiles of successful and unsuccessful Hmong secondary students (Publication No. 3039180) [Doctoral dissertation, University of California, Davis]. ProQuest Dissertations Publishing.

Vang, C. T. (2003). Learning more about Hmong students. Multicultural Education, 11 (2), 10- 14. https://files.eric.ed.gov/fulltext/EJ775324.pdf 
Vang, C. T. (2004). Hmong American K-12 students and the academic skills needed for a college education: A review of the existing literature and suggestions for future research. Hmong Studies Journal, 5(1),1-31. https://www.researchgate.net/publication/45088020 Hmong_American_K-12_Students_and the Academic_Skills_Needed_for_a_College Education_A_Review_of the Existing_Literature_and_Suggestions_for_Future Research

Vang, C. T. (2005). Hmong-American students still face multiple challenges in public schools. Multicultural Education 13(1), 27-35. https://files.eric.ed.gov/fulltext/EJ727805.pdf

Vang, C.Y. (2010). Hmong America: Reconstructing community in diaspora (Asian American experience). University of Illinois Press.

Voorhees, J., Goto, K., \& Wolff, C. (2014). Overweight, elevated blood pressure, acanthosis nigricans and adherence to recommended dietary and physical activity guidelines among Hmong and White middle school students. Journal of Immigrant and Minority Health, 16(2), 273-279. https://doi.org/ 10.1007/s10903-012-9739-7

Voorhees, J., Goto, K, Bianco-Simeral, S., \& Wolff, C. (2011). Impact of the Harvest of the Month Program on low-income Hmong and White middle school students. Journal of Nutrition Education and Behavior, 43(3), 152-154. https://doi.org/10.1016/j.jneb.2011.01.011

Xiong, Y.S. (2012). Hmong Americans' educational attainment: Recent changes and remaining challenges. Hmong Studies Journal, 13(2), 1-18. https://hmongstudies.org/ YSXiongHSJ13.2.pdf

Yang, D. (1992) Hmong at turning point. WorldBridge Partners, LLC.

Yav Pem Suab Academy. (2019). https://www.ypscharter.org 


\section{Appendix A}

Table A1. Mission, vision, and/or core/value/future/belief statements: Community School of Excellence (CSE).

\section{$\underline{\text { Mission }}$}

Community School of Excellence, a parent community partnership, provides a worldclass education through a caring and innovative environment that fosters inquiring, knowledgeable and compassionate students who embrace the Hmong culture and celebrate intercultural understanding and respect.

Educational Approach

CSE provides a culturally relevant model of education that addresses the diverse educational needs of students by:

- Integrating Hmong culture, language and literacy across all content areas.

- Setting high academic expectations for all students and providing additional intervention to students as needed.

- Providing high quality professional development focused on instructional best practices.

- Implementing a school-wide academic monitoring system enabling data- based decision making at the instructional level.

- Incorporating a secondary and postsecondary preparation focus to assist all students in understanding long-term career and college opportunities. 
Table A2. Mission, vision, and/or core/value/future/belief statements: Hmong American Peace Academy (HAPA).

\section{Mission}

Hmong American Peace Academy provides students with rigorous academics, character development, and Hmong cultural values, preparing them to excel in colleges, universities and careers.

Vision

Hmong American Peace Academy students enjoy college and career success, value Hmong cultural heritage, and exhibit responsible and peaceful leadership in local and global communities.

$\underline{\text { Core Values }}$

- Choice and commitment

- High expectations

- Results-driven

- Joyfulness

- Respect for relationships

- Hmong culture preservation

- Peace education

Visions for the Future

- Students are global citizens, peace builders, and leaders who act as a bridge between their Southeast Asian culture and mainstream American culture.

- Hmong American Peace Academy, Ltd. is internationally known as a state-of-the-art model for education in providing services to bilingual and bicultural students and their families, is a resource for meeting the needs of Hmong families and a center for sharing and celebrating Hmong history, culture, and language.

- Partnerships with the community provide knowledge, skills, and work opportunities in the core areas of medical, law, engineering, business, and humanities. 
Table A3. Mission, vision, and/or core/value/future/belief statements: New Millennium Academy (NMA).

\section{$\underline{\text { Mission }}$}

To build a better life for our students by creating an environment of high academic achievement while preserving Hmong Culture and literacy.

Vision

Inspiring learners who proudly lead meaningful lives to better our world.

Core Values

- Academic Achievement

- Hmong Culture and Literacy

- Accountability

- Collaboration

Table A4. HAPA student demographics. Student Racial/Ethnic Backgrounds

American Indian or Alaskan Native

Asian 0

Black or African American 97.7

Hispanic/Latino 0.6

Native Hawaiian or Other Pacific Islander

White 0.6

Two or More Races

0.2

Student Groups 0.4

Students with Disabilities 0.5

Economically Disadvantaged Percentage

English Learners 4.5

Total Number of Students 92.4 16.2 1,594 
Table A5. NMA history of student enrollment.

\begin{tabular}{ccccc}
\hline & Kindergarten & Grades 1-6 & Grades 7-8 & Total \\
\hline 2006 & 40 & 137 & 0 & 177 \\
2007 & 54 & 244 & 0 & 298 \\
2008 & 42 & 278 & 62 & 382 \\
2009 & 44 & 243 & 50 & 337 \\
2010 & 44 & 258 & 65 & 367 \\
2011 & 49 & 258 & 85 & 392 \\
2012 & 56 & 299 & 93 & 448 \\
2013 & 63 & 313 & 93 & 469 \\
2014 & 68 & 297 & 75 & 440 \\
2015 & 57 & 357 & 68 & 482 \\
2016 & 68 & 402 & 84 & 554 \\
2017 & 85 & 470 & 109 & 664 \\
\hline
\end{tabular}

Table A6. Student demographics at Noble Academy.

\begin{tabular}{cccc}
\hline Types & $\mathbf{2 0 1 6 - 2 0 1 7}$ & $\mathbf{2 0 1 7 - 2 0 1 8}$ & $\mathbf{2 0 1 8 - 2 0 1 9}$ (est.) \\
Total Enrollment & 861 & 953 & 1134 \\
Male & 438 & 496 & 584 \\
Female & 404 & 457 & 550 \\
Special Education & 36 & 50 & 60 \\
LEP & 476 & 509 & 492 \\
African American & 102 & 107 & 34 \\
Latino & 3 & 6 & 13
\end{tabular}


Table A7. Student enrollment number at Noble Academy.

\begin{tabular}{lccc}
\hline Grades & $\mathbf{2 0 1 6 - 2 0 1 7}$ & $\mathbf{2 0 1 7 - 2 0 1 8}$ & $\mathbf{2 0 1 8 - 2 0 1 9}$ (est.) \\
\hline Pre-Kindergarten & & 60 & 100 \\
Kindergarten & 111 & 125 & 122 \\
$1^{\text {st }}$ Grade & 112 & 114 & 134 \\
$2^{\text {nd }}$ Grade & 110 & 112 & 115 \\
$3^{\text {rd }}$ Grade & 111 & 116 & 139 \\
$4^{\text {th }}$ Grade & 115 & 113 & 118 \\
$5^{\text {th }}$ Grade & 92 & 114 & 119 \\
$6^{\text {th }}$ Grade & 84 & 90 & 117 \\
$7^{\text {th }}$ Grade & 80 & 91 & 94 \\
$8^{\text {th }}$ Grade & 46 & 78 & 76 \\
Total & 861 & 953 & 1134 \\
Total ADM (Average & 814.49 & 993.15 & 998.34 \\
Daily & & & \\
Membership) for & & & \\
year & & &
\end{tabular}

Table A8: CSE's student attrition numbers for 2017-2018 is 9.4\%.

\begin{tabular}{|c|c|c|c|c|c|c|}
\hline & $\begin{array}{l}\text { Student } \\
\text { Enrollment }\end{array}$ & $\begin{array}{l}\text { Enrolled } \\
\text { on } \\
\text { Oct. } 1\end{array}$ & $\begin{array}{l}\text { Enrolled } \\
\text { after } \\
\text { Oct. } 1\end{array}$ & $\begin{array}{l}\text { Exited } \\
\text { after } \\
\text { Oct. } \\
1\end{array}$ & $\begin{array}{l}\text { Enrolled } \\
\text { EOY }\end{array}$ & $\begin{array}{l}\text { Student } \\
\text { Group }\end{array}$ \\
\hline$\overline{\mathrm{KG}}$ & 125 & 137 & 10 & 3 & 139 & \\
\hline $1^{\mathrm{st}}$ & 117 & 121 & 9 & 5 & 125 & \\
\hline $2^{\text {nd }}$ & 125 & 130 & 3 & 2 & 131 & \\
\hline $3^{\text {rd }}$ & 113 & 117 & 6 & 6 & 115 & \\
\hline $4^{\text {th }}$ & 129 & 132 & 7 & 2 & 137 & \\
\hline $5^{\text {th }}$ & 115 & 117 & 6 & 1 & 121 & SpEd-10\% \\
\hline $6^{\text {th }}$ & 122 & 124 & 3 & 4 & 123 & $\begin{array}{l}\text { EL-642/1102 = } \\
58 \%\end{array}$ \\
\hline $7^{\text {th }}$ & 133 & 134 & 2 & 1 & 135 & $\begin{array}{l}\text { Free/R: } \\
958 / 1102= \\
87 \%\end{array}$ \\
\hline $8^{\text {th }}$ & 87 & 90 & 1 & 3 & 87 & \\
\hline Total & 1066 & 1102 & 47 & 27 & 1113 & \\
\hline
\end{tabular}


Table A9: HOPE staff Information.

\begin{tabular}{|c|c|c|c|}
\hline \multirow[t]{2}{*}{ Staff Category } & \multicolumn{3}{|l|}{ Year: March 2019} \\
\hline & Number of Staff & $\begin{array}{l}\text { Number of } \\
\text { Hmong } \\
\text { American } \\
\text { Staff }\end{array}$ & Percentage \\
\hline Administration & 1 & 1 & $100 \%$ \\
\hline Elementary teachers & 16 & 4 & $25 \%$ \\
\hline Middle School teachers & 6 & 0 & $0 \%$ \\
\hline Specialists & 21 & 5 & $24 \%$ \\
\hline Support staff & 23 & 18 & $78 \%$ \\
\hline Total & 67 & 28 & $42 \%$ \\
\hline
\end{tabular}

Table A10. Hmong College Prep Academy staff information.

\begin{tabular}{lc}
\hline Staff Information & $\begin{array}{c}\text { Number of Hmong American Staff/Overall } \\
\text { Number of Staff (Year-2018) }\end{array}$ \\
\hline Total Elementary School Staff & 69 \\
Total Hmong American & 9 out of the 69 \\
Elementary School Staff & 91 \\
Total Middle/High School Staff & $72 / 91$ \\
Total Hmong American & 160 \\
Middle/High School Staff & $81 / 160$ \\
$\begin{array}{l}\text { Grand Total HCPA Staff } \\
\text { Grand Total Hmong American }\end{array}$ & \\
Staff & \\
\hline
\end{tabular}


Table A11: Noble Academy staff information.

\begin{tabular}{|c|c|}
\hline Staff Information & $\begin{array}{l}\text { Number of Hmong American } \\
\text { Staff/Overall Number of Staff } \\
\text { (Year-2018) }\end{array}$ \\
\hline \multicolumn{2}{|l|}{ Administration } \\
\hline - $\quad$ Superintendent & $1 / 1$ \\
\hline - $\quad$ Deputy Superintendent & $1 / 1$ \\
\hline \multicolumn{2}{|l|}{ of Academics } \\
\hline \\
\hline Administrative assistant & $1 / 1$ \\
\hline health care specialist & $1 / 1$ \\
\hline human resource specialist & $1 / 1$ \\
\hline information technology & $2 / 2$ \\
\hline library media specialist & $1 / 1$ \\
\hline secretary & $1 / 1$ \\
\hline student accountant specialist & $1 / 1$ \\
\hline transportation specialists & $2 / 2$ \\
\hline \multicolumn{2}{|l|}{ Teachers } \\
\hline art & $0 / 0$ \\
\hline classroom teachers & $33 / 6$ \\
\hline $\begin{array}{l}\text { Hmong heritage, language, } \\
\text { culture and art }\end{array}$ & $3 / 3$ \\
\hline Music & $1 / 0$ \\
\hline physical education & $2 / 1$ \\
\hline special education & $4 / 2$ \\
\hline Custodians & $4 / 4$ \\
\hline Total & $59 / 28$ \\
\hline
\end{tabular}

Table A12. New Millennium Academy student proficiency-MN Accountability Test (MCA III).

\begin{tabular}{lllll}
\hline $\begin{array}{l}\text { 2018 } \\
\text { Results }\end{array}$ & Reading & \multicolumn{3}{c}{ Math } \\
\hline Grade & $\begin{array}{l}\text { Number of } \\
\text { students tested } \\
\text { (registered by }\end{array}$ & $\begin{array}{l}\text { Percentage of } \\
\text { tested } \\
\text { students } \\
\text { proficient }\end{array}$ & $\begin{array}{l}\text { Number of } \\
\text { students tested } \\
\text { (registered by } \\
\text { October 1, }\end{array}$ & $\begin{array}{l}\text { Percentage of } \\
\text { tested students } \\
\text { proficient }\end{array}$ \\
& October 1, 2017) & \\
& & & $2017)$ & \\
3 & 81 & $13.6 \%$ & 81 & $23.5 \%$ \\
4 & 79 & $12.7 \%$ & 77 & $22.1 \%$ \\
5 & 85 & $29.4 \%$ & 84 & $21.4 \%$ \\
6 & 75 & $22.7 \%$ & 74 & $10.8 \%$ \\
7 & 64 & $31.3 \%$ & 64 & $25.0 \%$ \\
8 & 46 & $37.0 \%$ & 46 & $32.6 \%$ \\
All & Total & 430 & Average 23.3\% Total 426 & Average 21.8\% \\
Grades & \multicolumn{4}{c}{} \\
\hline
\end{tabular}


Table A13. New Millennium Academy reading on track/proficiency report.

\begin{tabular}{|c|c|c|c|c|c|c|}
\hline & $\begin{array}{l}2013- \\
\text { reset } \\
\text { year }\end{array}$ & 2014 & 2015 & 2016 & 2017 & 2018 \\
\hline $\begin{array}{l}\text { On- } \\
\text { Track } \\
\text { Reading }\end{array}$ & $54.9 \%$ & $37.1 \%$ & $35.6 \%$ & $39.3 \%$ & $28.0 \%$ & $33.7 \%$ \\
\hline $\begin{array}{l}\text { Proficiency } \\
\text { Reading (Oct 1) }\end{array}$ & $25.4 \%$ & $26.9 \%$ & $30.1 \%$ & $28.7 \%$ & $22.6 \%$ & $23.8 \%$ \\
\hline $\begin{array}{l}\text { Number of } \\
\text { Students } \\
\text { Tested (Oct 1) }\end{array}$ & 268 & 249 & 266 & $\begin{array}{c}324 \\
\text { (increase } \\
\text { of } 58 \\
\text { students) }\end{array}$ & $\begin{array}{c}412 \\
\text { (increase } \\
\text { of } \\
88 \\
\text { students) }\end{array}$ & $\begin{array}{c}430 \\
\text { (increase } \\
\text { of } 18 \\
\text { students) }\end{array}$ \\
\hline
\end{tabular}

Table A14. New Millennium Academy math on track/proficiency report.

\begin{tabular}{ccccccc}
\hline & $\mathbf{2 0 1 3}$ & $\mathbf{2 0 1 4}$ & $\mathbf{2 0 1 5}$ & $\mathbf{2 0 1 6}$ & $\mathbf{2 0 1 7}$ & $\mathbf{2 0 1 8}$ \\
\hline On-Track Math & $58.5 \%$ & $74.9 \%$ & $63.3 \%$ & $66.4 \%$ & $34.3 \%$ & $26.6 \%$ \\
$\begin{array}{c}\text { Proficiency } \\
46.7 \%\end{array}$ & $60.1 \%$ & $55.3 \%$ & $51.2 \%$ & $37.1 \%$ & $21.8 \%$ \\
$\begin{array}{c}\text { Math (Oct. 1) } \\
\begin{array}{c}\text { Number of } \\
\text { Students }\end{array}\end{array}$ & 272 & 248 & 266 & $\begin{array}{c}324 \\
\text { (increase } \\
\text { of 58 } \\
\text { students) }\end{array}$ & $\begin{array}{c}412 \\
\text { (increase } \\
\text { of 88 } \\
\text { students) }\end{array}$ & $\begin{array}{c}426 \\
\text { (increase } \\
\text { of 14 } \\
\text { students) }\end{array}$
\end{tabular}

The increase in number of students tested (increase of 164 students in three years) reflects the overall growth of the school. NMA has experienced a significant drop in proficiency in Math. Reading has stayed rather consistent. Math continued to decline. Declining student performance in 2018 shows a lack of high and medium growth for both Reading and Math year to year. To increase student performance, NMA must ensure a majority of students making High to medium growth year after year. Additionally, NMA leadership must continue to review curriculum to close gaps in student performance. 
Table A15. Noble Academy's Proficiency Index, Reading.

\begin{tabular}{|c|c|c|c|c|c|c|}
\hline \multicolumn{7}{|c|}{ Proficiency Index, Reading } \\
\hline & $\begin{array}{l}\text { Noble } \\
\text { Academy }\end{array}$ & State & Osseo & $\begin{array}{l}\text { Minneapolis } \\
\text { School Dist. }\end{array}$ & $\begin{array}{c}\text { Prairie } \\
\text { Seeds } \\
\text { Academy }\end{array}$ & $\begin{array}{c}\text { Hmong } \\
\text { International } \\
\text { Academy }\end{array}$ \\
\hline FY2017 & $75.7 \%$ & $78.9 \%$ & $76.6 \%$ & $60.3 \%$ & $56.6 \%$ & $38.7 \%$ \\
\hline FY2016 & $64.6 \%$ & $69.4 \%$ & $68.0 \%$ & $52.4 \%$ & $43.6 \%$ & $31.6 \%$ \\
\hline FY2015 & $64.0 \%$ & $69.1 \%$ & $67.8 \%$ & $52.0 \%$ & $29.7 \%$ & $27.1 \%$ \\
\hline FY2014 & $61.1 \%$ & $58.8 \%$ & NA & $52.5 \%$ & $31.3 \%$ & $30.9 \%$ \\
\hline FY2013 & $53.8 \%$ & $68.0 \%$ & NA & $52.0 \%$ & $32.0 \%$ & $25.2 \%$ \\
\hline FY2012 & $71.1 \%$ & $69.0 \%$ & NA & $68.1 \%$ & $56.4 \%$ & $51.4 \%$ \\
\hline
\end{tabular}

Table A16. Noble Academy's Proficiency Rates, Reading.

\begin{tabular}{|c|c|c|c|c|c|c|}
\hline \multicolumn{7}{|c|}{ Proficiency Rates, Reading } \\
\hline & $\begin{array}{l}\text { Noble } \\
\text { Academy }\end{array}$ & State & Osseo & $\begin{array}{l}\text { Minneapolis } \\
\text { School Dist. }\end{array}$ & $\begin{array}{c}\text { Prairie } \\
\text { Seeds } \\
\text { Academy }\end{array}$ & $\begin{array}{l}\text { Hmong } \\
\text { International } \\
\text { Academy }\end{array}$ \\
\hline FY2017 & $52.2 \%$ & $60.2 \%$ & $56.3 \%$ & 43.2 & $27.2 \%$ & $18.9 \%$ \\
\hline FY2016 & $52.1 \%$ & $59.9 \%$ & $57.3 \%$ & $43.2 \%$ & $31.1 \%$ & $19 \%$ \\
\hline FY2015 & $54.5 \%$ & $59.5 \%$ & $56.7 \%$ & $45.6 \%$ & $19.3 \%$ & $15.6 \%$ \\
\hline FY2014 & $46.7 \%$ & $58.8 \%$ & NA & $42.4 \%$ & $18.3 \%$ & $16.8 \%$ \\
\hline
\end{tabular}

Table A17. Noble Academy's Proficiency Rates, Math.

\begin{tabular}{lcccccc}
\hline \multicolumn{2}{l}{ Proficiency Rates, Math } & & & & \\
\hline & $\begin{array}{l}\text { Noble } \\
\text { Academy }\end{array}$ & State & Osseo & $\begin{array}{c}\text { Minneapolis } \\
\text { School Dist. }\end{array}$ & $\begin{array}{c}\text { Prairie } \\
\text { Seeds } \\
\text { Academy }\end{array}$ & $\begin{array}{c}\text { Hmong } \\
\text { International } \\
\text { Academy }\end{array}$ \\
FY2017 & $59.8 \%$ & $58.7 \%$ & $54.2 \%$ & $42.6 \%$ & $32.8 \%$ & $18.5 \%$ \\
FY2016 & $61.7 \%$ & $59.5 \%$ & $54.4 \%$ & $44.1 \%$ & $32.7 \%$ & $24.3 \%$ \\
FY2015 & $65.7 \%$ & $60.2 \%$ & $57.1 \%$ & $45.0 \%$ & $28.1 \%$ & $22.5 \%$ \\
FY2014 & $70.5 \%$ & $60.5 \%$ & NA & $43.1 \%$ & $21.6 \%$ & $22.0 \%$ \\
FY2013 & $61.7 \%$ & $60.2 \%$ & NA & $42.2 \%$ & $17.7 \%$ & $18.9 \%$ \\
\hline
\end{tabular}


Table A18. CSE ACCESS student performance.

\section{Spring 2018 ACCESS Levels}

\begin{tabular}{cccccccc}
\hline Grades & Level 1 & Level 2 & Level 3 & Level 4 & Level 5 & Level 6 & Total Tested \\
K & 96 & 15 & 4 & 1 & 1 & 0 & 117 \\
1 & 2 & 34 & 44 & 13 & 1 & 0 & 94 \\
2 & 1 & 23 & 62 & 10 & 0 & 0 & 96 \\
3 & 2 & 11 & 51 & 31 & 1 & 0 & 96 \\
4 & 1 & 7 & 32 & 38 & 9 & 1 & 89 \\
5 & 2 & 2 & 15 & 36 & 6 & 0 & 61 \\
6 & 2 & 11 & 27 & 4 & 0 & 0 & 44 \\
7 & 2 & 12 & 28 & 21 & 1 & 0 & 64 \\
8 & 0 & 6 & 22 & 14 & 1 & 0 & 43 \\
All & 108 & 121 & 285 & 168 & 20 & 1 & 704 \\
\hline
\end{tabular}

NOTE: For more information about ACCESS, consult CSE's website. 


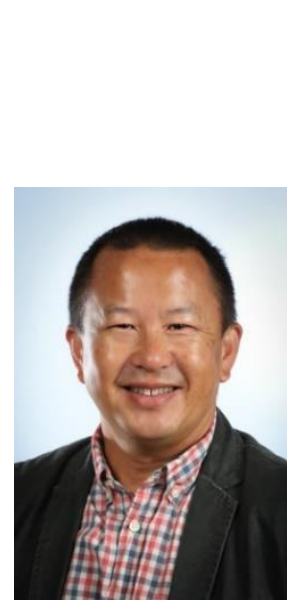

\section{About the Author}

Pao Lor holds the Patricia Wood Baer Professorship at the University of Wisconsin-Green bay and chairs the Professional Program in Education. 
Journal of Southeast Asian American

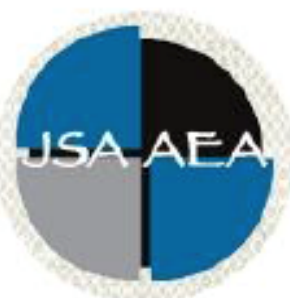

Vol.16 Iss.1 (2021)

\section{Education and Advancement}

\author{
Editor \\ Dr. Wayne E. Wright \\ Purdue University \\ Associate Editors \\ Dr. Chhany Sak-Humphry \\ University of Hawaii at Manoa \\ Dr. Phitsamay Sychitkokhong Uy \\ University of Massachusetts, Lowell \\ Book Review Editor \\ Dr. Vichet Chhuon \\ University of Minnesota \\ Creative Works Editor \\ Bryan Thao Worra \\ Lao Assistance Center \\ Journal Manager \\ Chen Li \\ Jeffrey Sovan Wright \\ Purdue University
}

\title{
Editorial Review Board
}

\author{
Dr. Steve Arounsack \\ California State University, Stanislaus \\ Dr. Sovicheth Boun \\ Salem State University \\ Dr. Virak Chan \\ Purdue University
}

Dr. Carl L. Bankston III

Tulane University

Dr. Phala Chea

Lowell Public Schools

Dr. George Chigas

University of Massachusetts, Lowell 


\author{
Dr. Loan Dao \\ University of Massachusetts Boston \\ Dr. Linh Dang \\ KIPP DC Headquarters \\ Dr. Sophal Ear \\ Occidental College \\ Dr. Vincent K. Her \\ University of Wisconsin, Eau Claire \\ Dr. Nancy H. Hornberger \\ University of Pennsylvania \\ Dr. Peter Tan Keo \\ New York University \\ Dr. Yvonne Kwan \\ San Jose State University \\ Dr. Ravy Lao \\ California State University, Los Angeles \\ Dr. Stacey Lee \\ University of Wisconsin, Madison \\ Dr. Jacqueline Mac \\ Northern Illinois University \\ Dr. Bic Ngo \\ University of Minnesota \\ Dr. Leakhena Nou \\ California State University, Long Beach \\ Dr. Mark Pfeifer \\ SUNY Institute of Technology \\ Dr. Loan T. Phan \\ University of New Hampshire \\ Dr. Karen Quintiliani \\ California State University, Long Beach \\ Dr. Angela Reyes \\ Hunter College \\ The City University of New York \\ Dr. Fay Shin \\ California State University, Long Beach \\ Dr. Christine Su \\ College of San Mateo \\ Dr. Alisia Tran \\ Arizona State University \\ Dr. Khatharya Um \\ University of California, Berkeley \\ Dr. Kim Tran \\ University of California, Los Angeles, \\ Glendale Community College \\ Dr. Molly Wiebe
}

The University of Texas at Austin
Dr. Hien Duc Do

San Jose State University

Dr. Changming Duan

University of Missouri-Kansas City

Dr. Sothy Eng

Lehigh University

Dr. Jeremy Hein

University of Wisconsin, Eau Claire

Dr. Peter Nien-Chu Kiang

University of Massachusetts, Boston

Dr. Kevin K. Kumashiro

University of Illinois, Chicago

Dr. Ha Lam

Independent Scholar

Dr. Jonathan H. X. Lee

San Francisco State University

Dr. Monirith Ly

Royal University of Phnom Penh

Dr. Sue Needham

California State University, Dominguez Hills

Dr. Max Niedzwiecki

Daylight Consulting Group

Dr. Clara Park

California State University, Northridge

Dr. Giang Pham

University of Massachusetts Amherst

Dr. Malaphone Phommasa

University of California Santa Barbara

Dr. Kalyani Rai

University of Wisconsin-Milwaukee

Dr. Cathy J. Schlund-Vials

University of Connecticut, Storrs

Dr. Nancy J. Smith-Hefner

Boston University

Dr. Yer J. Thao

Portland State University

Dr. Monica M. Trieu

Purdue University

Dr. Silvy Un

Saint Paul Public Schools

Dr. Linda Trinh Vo

University of California, Irvine

Dr. Varaxy Yi Borromeo

California State University, Fresno

Dr. Yang Sao Xiong

The University of Wisconsin-Madison 


\author{
Dr. Zha Blong Xiong \\ University of Minnesota
}

\title{
Doctoral Student Editorial Review Board
}

\author{
Diana Chandara \\ University of Minnesota-TwinCiteis \\ Linh Dang \\ University of Rochester \\ Annie BichLoan Duong \\ San Joaquin County Office of Education \\ Jacqueline Mac \\ Indiana University \\ Vanessa Sovanika Na \\ University of California SanDiego \\ Khoi Nguyen \\ George Mason University \\ Linda Marie Pheng \\ University of Wisconsin-Madison \\ Latana Thaviseth \\ University of California Los Angeles \\ Melissa Vang \\ San Diego State University \\ Soua Xiong \\ San Diego State University \\ Claremont Graduate University
}

\author{
Kassandra Chhay \\ University of Minnesota-Twin Cities \\ Bao Diep \\ University of Minnesota-Twin Cities \\ Nielson Hul \\ Cornell University \\ Dung Minh Mao \\ University of Minnesota-Twin Cities \\ Hoa Nha Nguyen \\ Boston College \\ Thien-Huong Ninh \\ University of Southern California \\ Krissyvan Truong \\ Claremont Graduate University \\ Mai Vang \\ University of Massachusetts Boston \\ Thong Vang \\ University of Minnesota-Twin Cities
}

